\title{
Arazi ve arsa düzenlemelerinin geri dönüşüm işlemlerinde yargı kararlarına dayalı öneriler
}

\author{
Sinem Hacıosmanoğlu ${ }^{1+(\mathbb{D})}$, Hülya Demir ${ }^{2}$ (D) \\ ${ }^{1}$ Ataşehir Belediyesi, Ataşehir, İstanbul, Türkiye. \\ ${ }^{2}$ Yıldız Teknik Üniversitesi, Davutpaşa Kampüsü, Inşaat Fakültesi, Harita Mühendisliği Bölümü, Esenler, Istanbul, Türkiye.
}

Öz: Imar planının hayata geçirilmesi aşamasında yapılan hukuki ve teknik hatalar ile eksiklikler, arazi ve arsa düzenleme (AAD) çalışmalarının idari yargıda açılan davalar sonucunda iptal edilmesine sebep olmaktadır. Öyle ki, ilgilisi tarafindan açılan davalar sonucunda yillar geçtikten sonra bile yürütmeyi durdurma ve iptal kararlar verilebilmektedir. AAD'yi yapan idareler ile düzenleme sonuçlarının kontrol ve tescil edildiği kadastro ve tapu müdürlükleri, AAD’nin iptali ardından yapılacak işlemler konusunda tereddütler yaşamaktadır. Bu nedenle iptal sonrası yapılacak geri dönüş işleminin doğru bir şekilde gerçekleştirilebilmesi için yol göstericinin olması oldukça önemlidir. Bu makalede, idari yargı kararı ile AAD’nin iptali sonucu oluşan yeni durumda, uygulayıcıların hukuka uygun bir biçimde geri dönüşüm yapabilmeleri için yol göstermek amaçlanmıştır. Bunun için öncelikle, AAD'nin iptal nedenleri; (1) yetki ve şekil eksikliği, (2) sebep, konu, maksat yönleriyle ele alınmıştır. Daha sonra, sebep, konu, maksat yönleriyle iptal edilen AAD’nin geri dönüşümü sırasında yapılacak işlemler; (1) genel işlemler ve (2) AAD sonrasında bölgede ya da parsellerde, mülkiyet velveya zemindeki fiili durum yönünden bir değişiklik yaratan işlemler olarak sınıflandırllarak her biri kendi içinde; (a) idari, (b) teknik, (c) hukuki işlem olup olmamalarına göre gruplandırılarak yargı kararları ışı̆̆ında incelenmiştir. Sonuç olarak AAD'nin geri dönüşümü işlemlerinde yargı kararlarına dayalı emsal olabilecek durumlar çıkarılmış ve iş süreçleri tanımlanmıştır.

Anahtar Sözcükler: Arsa ve arazi düzenlemesi, Arsa ve arazi düzenlemesi iptali, Kök parsel, Kök parsele dönüş, Geri dönüşüm, İmar uygulamalarının geri dönüşümü

\section{Suggestions on the reversing process of the land readjustment based on judicial decisions}

Abstract: Legal and technical errors and deficiencies made during the implementation of the development plan may lead to the cancellation of the land readjustment $(L R)$ as a result of the lawsuits filed in the administrative judiciary. So much so that, as a result of the lawsuits filed by the related person, even many years have passed, stay of execution and cancellation decisions can be adopted. Following the cancellation of the LR, corporations/administrations, which prepared the LR project, and the directorates of land registry and cadastre, who are responsible for checking and registering the readjustment results, have hesitations about the actions to be taken. Therefore, it is important to have course of action in order to reverse the process correctly. In this paper, it is aimed to guide the practitioners to perform the reversing process in compliance with the law in the new situation which has occurred as a result of the cancellation of the LR by the administrative justice decision. To this end, first of all, the reasons for the cancellation of LR were discussed in terms of (1) lack of authority and form; (2) reason, subject and purpose. Then, the procedures to be followed during the reversing process of the LR cancelled in terms of reason, subject, purpose were categorized under (1) general procedures and (2) procedures that create a change in the territory or parcels regarding property and/or de facto situation on the soil after the LR, and each were grouped according to whether they were (a) administrative, $(b)$ technical, or $(c)$ legal proceedings and examined in the light of judicial decisions. As a result, precedent cases were determined based on judicial decisions in the reversing process of the LR, and work processes were defined.

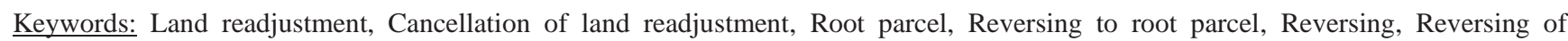
development applications 


\section{Giriş}

Arazi ve arsa düzenleme (AAD) işlemlerinin iptali istemleri, idari yargıda iki aşamada incelenmektedir. İlk olarak, açılan dava için ön koşulların incelemesi yapılır. Ön koşullar bakımından eksiği bulunmayan davada, bu kez işlemin esasına (özüne) ilişkin incelemeye geçilir. Bu aşamada, AAD işlemlerinin, hukuka aykırılık nedenleri ve hangi açılardan idari işlemin iptal edileceği incelenir. Dava açma ehliyetine sahip davacılar tarafindan idari yargılama usulüne uygun şekilde açılan davalarda, AAD işlemi ve dayanağı imar planı esas yönünden incelenebilmektedir.

2577 Sayılı İdari Yargılama Usulü Kanunu’nun “İdari dava türleri ve idari yargl yetkisinin sınırı” başlıklı 2'nci maddesinin a bendi uyarınca, idari yargıda yetki, şekil, sebep, konu ve amaç yönlerinden yasanın öngördüğü koşulları taşımadığı saptanan işlem, sakat demektir. AAD işleminin yetki yönünden incelenmesi, kanunların ve uygulama yönetmeliklerinin AAD işlemini yapma yetkisi verdiği idareler ve idarelerin yetki sahaları ile ilgilidir. Şekil yönünden inceleme, bölgede uygulanacak AAD yönteminin belirlenmesi, düzenleme sınırının geçirilmesi, düzenleme ortaklık payı (DOP) oranının belirlenmesi gibi AAD işleminin teknik yönü ile ilgilidir. Sebep yönünden hukuka uygun olması, işlemde AAD ile ilgili hukuk kurallarının öngördüğü şartların bulunmasını gerektirir. AAD işleminin konusu, imar hududu içinde bulunan binalı veya binasız arsa ve arazileri maliklerinin veya diğer hak sahiplerinin onayı aranmaksızın, birbirleri ile, yol fazlaları ile, kamu kurumlarına veya belediyelere ait bulunan yerlerle birleştirmek, bunları yeniden imar planına uygun ada veya parsellere ayırmak, müstakil, hisseli veya kat mülkiyeti esaslarına göre hak sahiplerine dağıtmak ve re'sen tescil işlemlerini yapmaktır. AAD işleminin bu hususlara aykırı şekilde yapılması ya da uygulama/ıslah imar planında öngörülen kullanım amacına uygun olarak yapılmaması, AAD işleminin konu bakımından yanlışlığına sebep olmaktadır. AAD işleminin amacı, tüm idari işlemlerde olduğu gibi kamu yararının sağlanmasıdır. Eğer AAD, siyasi çıkar, kişisel çıkar veya nefret, kin gibi nedenlerle yapılırsa, amaç unsuru yönünden hukuka aykırı hale gelmektedir (Kalabalık, 2014).

Bir bireysel idari işlem olan AAD’nin idari yargıda iptal edilmesi için, tescilin dayanağı olan encümen kararlarının iptal edilmesi gerekmektedir (Köktürk, 2009). AAD işleminin idari yargıda iptal edilmesiyle; AAD işlemi ile oluşan tüm kayıtlar, hukukî dayanaktan ve sebepten yoksun kalmaktadır. Türk Medeni Kanunu'nun "İyi niyetli olmayan üçüncü kişilere karşı” tescilin sonuçlarının açıklandığı 1024'üncü maddesinin 2'nci fıkrasına göre, “Bağlayıcı olmayan bir hukuki işleme dayanan veya hukuki sebepten yoksun bulunan tescil yolsuzdur.” AAD işleminin idari yargıda iptali ile birlikte, tapu kütüğündeki kayıt/kayıtlar Türk Medeni Kanunu’nun 1024'üncü maddesine göre “yolsuz tescil” durumuna düşerek geçersiz hale gelir.

Anayasanın 138'nci maddesinin son fikrasında “...Yasama ve Yürütme Organlarl ile idare mahkeme kararlarına uymak zorundadır; bu organlar ve idare, mahkeme kararlarını hiç bir suretle değiştiremez ve bunların yerine getirilmesini geciktiremez..." hükmedilmiş; 2577 sayılı İdari Yargılama Usulü Kanunu'nun “Kararların Sonuçları” başlıklı 28'nci maddesinin 1'inci fikrasındaki “...Danıştay, bölge idare mahkemeleri, idare ve vergi mahkemelerinin esasa ve yürütmenin durdurulmasına ilişkin kararlarının icaplarına göre idare, gecikmeksizin işlem tesis etmeye veya eylemde bulunmaya mecburdur. Bu süre hiçbir şekilde kararın idareye tebliğinden başlayarak otuz günü geçemez...” kuralı ile anayasanın 2'nci maddesindeki “Hukuk Devleti” ilkesine ve 138'nci maddesine uygun bir düzenleme yapılmıştır. Bu durumda işlemi yapan idare, makul bir süre içerisinde hatalı işlemini düzeltmeli veya geri almalı, yerine hukuka uyarlı işlem tesis etmelidir.

AAD, yetki ve şekil eksikliği yönünden hukuka aykırı bulunarak iptal edildiyse; idarece aynı yolla bir idari karar alınarak bu eksik giderilebilmektedir. Ancak AAD, sebep, konu ve maksat yönlerinden iptal edilmişse; bu durumda işlemin tamamen yok sayılması ve yapıldığı tarihten başlayarak makul bir süre içerisinde ortadan kaldırılması gerekmektedir. AAD’nin tamamı iptal edildiğinde, düzenleme öncesine dönülmesi zeminde fiili yapılaşma henüz oluşmamışsa kolay olmaktadır. Yapılaşmanın 
olduğu bölgelerde ise geri dönüş teknik olarak mümkün olmakta, ancak geri dönüş ile birlikte yeni bir AAD yapılmaması halinde uygulama açısından zorluklar yaşanmaktadır. Münferit olarak; tek bir parsel için iptal kararı verildiğinde ise; bu parselin diğerlerinden ayrı tutularak düzenleme öncesine döndürülmesi teknik olarak olanaksızdır. Ancak, yargının iptal kararına kadar geçen süre içinde tapu sicilinde, kat mülkiyeti tesisleri, çeşitli irtifak hakkı tesisleri, malik değişimleri, ipotek tesisleri, bağış, terk gibi taşınmazın hukuki durumu ile maliklerin hisse durumunu değiştiren işlemler olabilmektedir. Yıllar sonra gelen iptal kararının uygulanması aşamasında, bu gibi değişimlerle ilgili olarak mevzuatta herhangi bir düzenleme bulunmadığından, değişimlerin geri dönüşüm cetvellerine nasıl aktarılacağı, dolayısıyla yeni dağıtım cetvellerinin nasıl oluşturulacağı konularında tereddütler oluşabilmektedir.

Danıştay ve Yargıtay dairelerince verilen kararlar, mevzuatta açıkça belirtilmeyen hususlarda emsal ya da içtihat olarak değerlendirilmektedir. AAD’nin hukuka uyarlık taşımadığının tespit edilmesi sonucu yapılacak işlemler konusunda da, Danıştay ve Yargıtay nazarında genel bir düşünce ve içtihat oluşmuş bulunmaktadır. Bu bağlamda makalede, emsal niteliğindeki yargı kararları dikkate alınarak geri dönüşüm işlemindeki önemli hususlara ve karşılaşılan sorunlara çözüm önerileri getirmek amaçlanmıştır.

\section{Yöntem}

İlk aşamada, AAD’nin iptal nedenleri; (1) yetki ve şekil eksikliği, (2) sebep, konu, maksat yönleriyle ele alınmıştır. İkinci aşamada, iptal edilen AAD'nin geri dönüşümü sırasında yapılacak işlemler; (1) genel işlemler ve (2) AAD sonrasında bölgede ya da parsellerde, mülkiyet ve/veya zemindeki fiili durum yönünden bir değişiklik yaratan işlemler olarak sınıflandırılarak her biri kendi içinde; (a) idari, (b) teknik, (c) hukuki işlem olup olmamalarına göre aşağıdaki biçimde gruplandırılmıştır:

(1) Genel işlemler

(a) İdari işlemler

1. Mahkeme kararının tebliğinden itibaren 30 gün içinde iptal kararının uygulanması

2. AAD'nin iptal kararının idarece yerine getirilmesi mecburiyeti

3. İdarenin onay kurulu kararının 2981 sayılı Kanun'un 10'uncu maddesinin (b) bendine göre alınmış olması durumunda geri dönüşüm

4. AAD işlemi parsel bazında sebep, konu ve maksat yönlerinden iptal edilmişse yapılması gerekenler

5. İmar planı iptallerinde AAD’nin de iptal olup olmayacağı

6. İdarelerin geri dönüşüm işleminden sonra yeni bir AAD yapma mecburiyeti olup olmadığı

(b) Teknik işlemler

1. Geri dönüşüm işlemi yapmadan, mevcut imar parselleri üzerinden yeni bir uygulama yapılıp yapılamayacağı

2. Bağışların ve rızai terklerin geri dönüşümü

3. Kamusal ortaklık payına (KOP) giden kısmın geri dönüşümü

4. Geri dönüşüm hesapları ile kadastral parseldeki yüz ölçümün uyuşmaması durumunda geri dönüşüm 
(c) Hukuki işlemler

1. İkinci AAD işlemi yapılması koşulları

2. İdarece iptal kararının gereği yapılmazsa ilgilisince yapılacak işlem

3. İptal kararı gereğince tapu müdürlüğünce işlemin düzeltilip düzeltilemeyeceği

(2) AAD sonrasında bölgede ya da parsellerde, mülkiyet ve/veya zemindeki fiili durum yönünden bir değişiklik yaratan işlemler:

(a) Teknik işlemler

1. İptal edilen AAD ile oluşan parsellerin el değiştirerek üçüncü kişilerin mülkiyetine geçmesi durumunda geri dönüşüm (Malik değişikliği/hak değişikliği durumunda geri dönüşüm)

2. İptal edilen AAD ile oluşan parsellerin el değiştirerek üçüncü kişilerin mülkiyetine geçmesi durumunda DOP'a giden kısımların geri dönüşümü

3. İptal edilen AAD ile oluşan parsellerde kat mülkiyeti/kat irtifakı tesis edilmiş ise geri dönüşüm

4. İptal edilen AAD kapsamında oluşan bir imar parseli ile bu AAD sahası sınırları dışında kalan bir parselin tevhidi işlemlerinde geri dönüşüm

5. İmar parseli satılmışsa KOP’a giden kısmın geri dönüşümü

6. Malikler arası ipoteklerin tapu sicilinden terkin edildiği durumda geri dönüşüm

7. Malikler arası ipoteklerin tapu sicilinden terkin edilmediği durumda geri dönüşüm

Sınıflandırması yapılan işlemler, İdare Mahkemesi, Danıştay, Yargıtay ve Anayasa Mahkemesi tarafından alınan çözüme yönelik, emsal nitelikli kırkın üzerinde karar (Tablo 1) dikkate alınarak incelenmiş ve bunlara uygun olarak geri dönüşüm işlemlerinde neler yapılabileceği çıkarılmıştır (Akış, 2014; Koçak \& Beyaz, 2015; URL-1-10).

\section{Anahtar Kavramlar}

\subsection{Yolsuz Tescil}

Tapu kütüğündeki tescil ve devren kazanımların, herkese karşı ileri sürülebilmesi ve hak kazandırıcı görevini görebilmesi için o işlem ve dayanağı hukuka uygun olmalıdır. Tapu kütüğünde resmi şekilde düzenlenmeyen işlemler geçersizdir. Çünkü, yapılan tescilin, kendisinden beklenen sonucu meydana getirebilmesi; diğer bir ifade ile geçerliliğini sürdürebilmesi için öncelikle dayandığı bir hukukî sebebin bulunması ve bu sebebin de geçerli olması gerekir. Hiçbir hukukî dayanağı bulunmayan veya mevcut hukukî sebebi geçerli olmayan tesciller yolsuzdur. Bu durum, Türk Medeni Kanunu'nun 1024'üncü maddesinin 2'nci fikrası ile açıklanmıştır: “Bağlayıcı olmayan bir hukuki işleme dayanan veya hukuki sebepten yoksun bulunan tescil yolsuzdur." Yargitay 1'inci Hukuk Dairesi’nin 2014/1517 Esas, 2014/4385 Karar say1l1, 26.02.2014 tarihli kararında, "Bilindiği üzere, tapu kaydının illeti ve sebebi sayılan idari işlemin iptal edilmesi halinde, bu suretle oluşan kayıtların yolsuz tescil durumuna düşeceği, öte yandan idari işlemi iptal eden İdari Yargl kararının niteliği itibariyle önceki kayıtları kendiliğinden ihyâ etmeyeceği kuşkusuzdur. ” şeklinde ifade edilmiştir. Bir işlemin dayanağının ve sebebinin hukuka uygun olması, o işlemin yaşam kaynağıdır. Dayanağı ve sebebi hukuka uygun olmayan işlemler, tescil edilse bile sağlıklı ve geçerli hukuki bir sonuç doğurmaz. Yargıda açılacak dava ile tapu kaydındaki tescilin iptali istenebilir. Yargı kararı ile, dayanağı ve sebebi hukuka aykırı tespit edilerek iptal edilen işlemin varlığı ve yaşam kaynağı ortadan kaldırılmaktadır. Buna 
göre oluşturulan AAD ile oluşan imar tescilleri sebepten ve illiyetten yoksun hale gelir ve geçmişi de kapsayacak şekilde yolsuz tescile dönüşür.

İmar Kanunu'nun “Parselasyon planlarının hazırlanması ve tescili” başlıklı 19'uncu maddesinin 1'inci fikrasındaki, “Imar planlarına göre parselasyon planlart yapılıp, belediye ve mücavir alan içinde belediye encümeni, dışında ise il idare kurulunun onayından sonra yürürlüğe girer." hükmü ile, AAD işleminin tapu müdürlüğünce tescilinin dayanağ1 ve sebebi, ilgili idarenin alacağı karar olarak belirtilmiştir. AAD’de tapu kaydının dayanağı olan sebep, "belediye" veya "valilik" tarafından alınan karardır. Bu sebeple, AAD işleminin idari yargıda iptal edilmesi için, tescilin dayanağı olan encümen kararlarının iptal edilmesi gerekmektedir. Encümen kararının yargı kararı ile iptal edilmesiyle, tapu kütüğüne tescil edilen düzenleme sonuçlarının yanlış bir idari tasarruftan ileri geldiği ve hukuksal dayanaktan yoksun olduğu ortaya çıkar. Böylelikle, tapu kütüğündeki kayıt/kayıtlar, Türk Medeni Kanunu'nun 1024'üncü maddesine göre “yolsuz tescil” durumuna düşerek geçersiz hale gelmektedir.

Yargıtay 1'inci Hukuk Dairesi'nin 1994/1514 Esas, 1994/1963 Karar sayılı ve 18.02.1994 tarihli kararında, “Imar Kanunu'na göre; belediyeler tarafindan gerçekleştirilen parselasyon (şuyulandırma) işlemleri, idari teknik nitelik taşıyan işlemlerdendir. Bu türdeki işlemlere karşı idari yargı yerinde dava açılır ve işlemin iptali sağlanırsa, buna göre oluşturulan imar tescilleri sebepten ve illiyetten yoksun hale gelir ve geçmişi de kapsayacak şekilde yolsuz tescile dönüşür. Böyle bir durumun ortaya çıkması ile de kadastral mülkiyet ihyası (eski haline getirilmesi) ve kadastral mülkiyete dayanılarak adli yargl yerinde el atmanın önlenmesi davalarının açılabilmesi olană̆ı doğar.” denilmek suretiyle el atmanın önlenmesi davası açılabileceği (Akış, 2014); Yargıtay Hukuk Genel Kurulu'nun 1995/1-109 Esas, 1995/397 Karar say1l1, 19.04.1995 tarihli kararında, “...imar tapusuna esas alınan idari kararın, Idare Mahkemesinde ilgililer aleyhine açılacak bir dava ile iptal edilmesi, İdare Mahkemesi kararının kesinleşmesinden sonra genel mahkemede tapunun iptal ve tescili için dava açması zorunludur. Aksi halde, mülkiyet hakkının yetkisiz mercilerle alınan tek yanlı idari kararlarla ortadan kaldırılması veya zedelenmesi gibi taşınmaz mülkiyetinin genel kurallarına aykırı bir sonuç doğmuş, tapu sicili tutulmasının amacı ve önemi göz ardl edilmiş olur." denilmek suretiyle tapunun iptal ve tescil davası açılabileceği yüksek mahkeme kararlarında açıklanmıştır.

\subsection{Kazanılmış Hak}

AAD işlemlerinin mahkeme tarafından iptali sonrası, kazanılmış haklar gözetilerek geri dönüşüm işlemleri yapılmalıdır. Böylelikle ilgililerinin mülkiyet hakkı ihlal edilmeyecek ve geri dönüşüm çalışması konusunda idareye açılacak muhtemel iptal veya yürütmeyi durdurma istemli davaların önüne geçilecektir.

Anayasa Mahkemesi'nin 1972/51 Esas, 1973/4 Karar sayılı, 25.01.1973 tarihli kararında, “Kazanılmış hak kavramı, daha çok özel mülkiyet hakkı alanı içinde etki yapan bir hukuk kuralıdır." denilmek suretiyle, kazanılmış hakkın daha çok bir eşyaya (bütünleyici parça ve eklentisi ile) sahip bireylerin hak ve menfaatlerini korumak üzere geliştirilmiş olduğu vurgulanmıştır. Ak1 (1993), kazanılmış hakkı; “önceden yürürlükte bulunan hükümlere göre bir kişi yararına olan bir hakkın sonradan çıkartılan hükümlerle çiğnenememesi” şeklinde tanımlamaktadır. 
Tablo 1: AAD işlemlerinin idari yargı tarafından iptali sonrası çözüme yönelik yargı kararları

Sinıfi Türü

İşlem

Mahkeme kararının tebliğinden itibaren
30 gün içinde iptal kararının
uygulanması

AAD'nin iptal kararının idarece yerine getirilmesi mecburiyeti
İlgili Yargı Kararları

Danıştay 6'ncı Dairesi'nin 1998/4313 Esas, 1999/4953 Karar sayıl1, 19.10.1999 tarihli kararı; Danıştay 8'inci Daire'sinin 1981/1955 Esas, 1982/1293 Karar say1l, 01.11.1982 tarihli karar1.

Danıștay 1'inci Dairesi'nin 1999/82 Esas, 1999/98 Karar sayıl1, 02.06.1999 tarihli kararı; Danıștay 1'inci Dairesi'nin 1999/15 Esas, 1999/23 Karar sayıl1, 05.02.1999 tarihli kararı; Danıştay 1'inci Dairesi'nin 1984/221 Esas, 1984/218 Karar sayll, 05.10.1984 tarihli kararı; Danıștay 6'ncı Dairesi'nin 1995/7076 Esas, 1996/4029 Karar sayılı, 09.10.1996 tarihli kararı; Danıştay 6'nc1 Dairesi'nin 1992/334 Esas, 1992/348 Karar say1l,, 12.11.1992 tarihli kararı; Yargitay 1'inci Hukuk Dairesi'nin 2004/11454 Esas, 2004/12516 Karar say1l1, 04.11.2004 tarihli karar1.

İdarenin onay kurulu kararının 2981 Danıștay 6’ncı Dairesi'nin, 1998/724 Esas, 1999/563 Karar sayılı Kanun'un 10'uncu maddesinin (b) $\quad$ sayıl1, 04.02.1999 tarihli kararı.

bendine göre alınmış olması durumunda geri dönüșüm

AAD işlemi parsel bazında sebep, konu
ve maksat yönlerinden iptal edilmişse
yapılması gerekenler

Danıştay 6'ncı Dairesi'nin, 2004/1082 Esas, 2006/953 Karar, 08.03.2006 tarihli kararı; Yargitay 1'inci Hukuk Dairesi'nin 2014/1517 Esas, 2014/4385 Karar say1l1, 26.02.2014 tarihli kararı; Danıştay 6. Dairesi'nin 1998/4313 Esas, 1999/4953 Karar say1l, 19.10.1999 tarihli kararı.

İmar planı iptallerinde AAD'nin de iptal Danıstay 6'ncı Dairesi'nin 1997/6950 Esas, 1998/5903 Karar olup olmayacağı $\quad$ sayılı, 30.09.1998 tarihli kararı; 2003/1709 Esas, 2004/26 Kara sayıl1, 12.01.2004 tarihli karari; 2002/2844 Esas, 2003/5224 Karar sayılı, 28.10.2003 tarihli kararı ve 1999/3994 Esas, 2000/5332 Karar say1l, 24.10.2000 tarihli karar1. İdarelerin geri dönüşüm işleminden
sonra yeni bir AAD yapma mecburiyeti
olup olmadığ 1 Danıştay 6'ncı Dairesi'nin 1994/4947 Esas, 1995/1985 Karar

Geri dönüşüm işlemi yapmadan, mevcut Danıştay 6'ncı Dairesi'nin 2002/2368 Esas, 2003/5127 Karar imar parselleri üzerinden yeni bir sayılı, 24.10.2003 tarihli kararı; Yargitay 1'inci Hukuk uygulama yapılıp yapılamayacağı Dairesi'nin 2005/14270 Esas, 2006/2701 Karar, 17.03.2006 tarihli ve 2004/2524 Esas, 2004/3027 Karar, 17.03.2004 tarihli karar1.

Teknik $\quad$ Bağışların ve rızai terklerin geri $\quad$ Anayasa Mahkemesi’nin 12.01.2012 tarihli ve 2011/23 Esas, dönüşümü

2012/3 Karar sayılı kararı; Anayasa Mahkemesi Başkanlığı'nın 2014/11994 Başvuru numaralı başvuru için 9/3/2017 tarihli kararı; Anayasa Mahkemesi Başkanlığı'nın 2014/10857 Başvuru numaralı başvuru için 11/1/2017 Karar Tarihli, 24/2/2017 tarih ve 29989 sayılı Resmi Gazete'de yayımlanan kararı.

İkinci AAD işlemi yapılması koşulları Danıştay 6'ncı Dairesi'nin 2006/991 Esas, 2008/968 Karar sayıl1, 15.02.2008 tarihli kararı; Danıştay 6'ncı Dairesinin 1999/1215 Esas, 2000/1847 Karar say1l, 04.04.2000 tarihli karar1. \begin{tabular}{cc}
\hline İdarece iptal kararının gereği yapılmazsa & Danıştay 6'ncı Dairesi'nin 2008/8952 Esas, 2009/406 Karar \\
ilgilisince yapılacak ișlem & sayılı, 19.01.2009 tarihli kararı; Danıștay 6'ncı Dairesi'nin
\end{tabular} ilgilisince yapılacak ișlem 1995/7076 Esas, 1996/4029 Karar say1l1, 09.10.1996 tarihli kararı; Yargitay 1'inci Hukuk Dairesi'nin 29.04.1993 tarihli ve 1993/866 Esas, 1993/5535 Karar sayıl1 karar1; Yargitay 1'inci Hukuk Dairesi'nin 1997/4601 Esas, 1997/5035 Karar sayıl1, 14.04.1997 tarihli kararı; Yargitay 1'inci Hukuk Dairesi'nin 1994/1514 Esas, 1994/1963 Karar say1l1, 18.02.1994 tarihli kararı; Yargitay Hukuk Genel Kurulu'nun 1995/1-109 Esas, 1995/397 Karar sayıl1, 19.04.1995 tarihli kararı.

İptal kararı gereğince tapu müdürlüğünce işlemin düzeltilip düzeltilemeyeceği

İptal edilen AAD ile oluşan parsellerin el değiștirerek üçüncü kișilerin mülkiyetine geçmesi durumu (Malik değişikliği/hak değişikliği durumunda geri dönüşüm)

İptal edilen AAD ile oluşan parsellerin el değiştirerek üçüncü kişilerin mülkiyetine geçmesi durumunda düzenleme ortaklık payına giden kısımların durumu

$\begin{array}{ccc}\begin{array}{c}\text { AAD sonrasında } \\ \text { bölgede ya da } \\ \text { parsellerde, mülkiyet } \\ \text { ve/veya zemindeki fiili }\end{array} & \text { Teknik } & \begin{array}{c}\text { payına giden kısımların durumu } \\ \text { Iptal edilen AAD ile oluşan parsellerde } \\ \text { kat mülkiyeti/kat irtifakı tesis edilmesi } \\ \text { durumu }\end{array}\end{array}$

Yargitay 1'inci Hukuk Dairesi'nin 2014/1517 Esas, 2014/4385 Karar sayıl1, 26.02.2014 tarihli kararı.

Yargitay 1'inci Hukuk Dairesi'nin 2006/3554 Esas, 2006/4865

Karar sayıl1 27.04.2006 tarihli kararı; Danıștay 10'uncu Dairesinin 22.04.2013 tarihli, 2012/6474 Esas, 2013/3575 Karar sayılı kararı.

İstanbul 4'üncü İdare Mahkemesi'nin 2018/704 sayılı 12.06.2018 tarihli kararı.

Danıştay 6'ncı Dairesi'nin 2004/968 Esas, 2004/5379 Karar sayıl1, 04.11.2004 tarihli kararı; Danıştay 6'ncı Dairesi'nin 2003/3434 Esas, 2004/6885 Karar say1l, 22.12.2004 tarihli kararı; Danıştay 6'ncı Dairesi'nin 2002/4645 Esas, 2004/685 Karar sayıl1, 11.02.2004 tarihli kararı; Danıştay 6'ncı Dairesi'nin 2003/2547 Esas, 2004/6226 Karar sayıl1 07.12.2004 tarihli kararı; 2010/9076 Esas, 2011/469 Karar say1l1, 07.03.2011 tarihli karar1; 2003/3435 Esas, 2004/6378 Karar say1l1, 08.12.2004 tarihli karar1

İptal Edilen AAD kapsamında oluşan bir imar parseli ile bu AAD sahası sınırları dışında kalan bir parselin tevhidi durumu
Danıştay 6'ncı Dairesi'nin, 2002/2368 Esas, 2003/5127 Karar sayıl1, 24.10.2003 tarihli kararı; Danıştay 6'ncı Dairesi'nin, 2004/1082 Esas, 2006/953 Karar sayıl1, 08.03.2006 tarihli kararı. 
Danıştay, kazanılmış hakkın var olup olmadı̆̆ını saptarken, genel hukuk kurallarının kişilerin haklarına uygulanıp uygulanmadığını araştırmaktadır. Danıştay İçtihatları Birleştirme Kurulu’nun 1989/1-2 Esas, 1989/2 Karar sayılı, 14.06.1989 tarihli kararında, "kural tasarruflarla kabul edilen hukuksal olay ve esaslar kişisel durumlara dönüşmedikçe, kazanılmış hakların varlı̆̆ından söz edilemez.” denilmektedir. Buna göre, bir hakkın bir kişi tarafından kazanıldığının kabul edilebilmesi için, geçerli hukuk kuralı kişi hakkında uygulanmış olmalıdır. Kazanılmış hak, Danıştay 8'inci Dairesi’ nin 1974/4918 Esas, 1976/376 Karar sayılı, 03.02.1976 tarihli kararında, “hukuka uygun olarak alınan bir işlem sonucu elde edilen bir hak” olarak; Danıştay 1'inci Dairesi' nin 1992/224 Esas, 1992/238 Karar sayıl1, 13.07.1992 tarihli kararında, “eski kanun yürürlükte iken kesin bir surette kazanılan, yani hukukça korunmakta bulunan ve bir iddia haline gelen haklar" şeklinde tanımlamıştır.

Yargıtay 9'uncu Hukuk Dairesi’nin 1982/8329 Esas, 1982/9353 Karar sayılı, 26.11.1982 tarihli kararına göre kazanılmış hak, "yasalara uygun olarak gerçekleşen hak" olarak tanımlanmaktadır. Bu kapsamda, haksız ve hukuka aykırı uygulamalar kazanılmış hak yaratmamaktadır.

İdari işlemden doğan bir hakkın, kazanılmış hak olarak kabul edilip korunabilmesi için öncelikle üç koşul birlikte gerçekleşmelidir: (1) hakkın bireysel idari işlemden doğmuş olması; (2) bireysel idari işlemin tesis edildiği anda geçerli hukuk kurallarına aykırı olmaması; (3) hakkın kişi açısından kesinleşmiş olmasıdır. Bu koşulların her üçünün birlikte gerçekleşmesi halinde, hakkın geçmişe ilişkin boyutunun her zaman korunacağ1; iki koşulun gerçekleşmesi halinde, hakkın geleceğe ilişkin boyutunun prensip olarak korunmakla birlikte, korunmayacağı istisnai durumların da olabileceği; hakkın geleceğe ilişkin kullanımı aynı zamanda kamu düzenini bozucu veya kamu hizmetini aksatıcı ve hatta kamu hizmetinin daha iyi yürütülmesini engelleyici sonuç doğuracaksa, bu hakkın geleceğe ilişkin boyutunun (etkisinin) korunamayacağı, bu halde idarenin, yapacağı kaldırma veya değiştirme işlemi ile söz konusu hakkın geleceğe ilişkin etkisine son vermek zorunda olduğu belirtilmiştir (Ulusoy, 2004).

Tütüncü (2015)'e göre, kanunlar bir hakkın doğum koşullarını ya da doğmuş bir hakkın sonuçlarını değiştirdiği zaman kazanılmış hak kavramına başvurma zorunluluğu ortaya çıkmaktadır.

Haksız ve hukuka aykırı uygulamalar kazanılmış hak yaratmamaktadır. Bireysel idari işlemin tesis edildiği andaki geçerli hukuk kurallarına aykırılığı tespit edilerek yargı kararı ile iptal edilen bir AAD, kazanılmış hak yaratmayacağından, söz konusu işlemler hukuka uyarlı hale getirilmek amacıyla geriye yürütülebilmektedir.

Geri alma işlemi ile kazanılmış hakların korunması arasında sıkı bir ilişki vardır. Danıştay 8'inci Daire'sinin 1981/1955 Esas, 1982/1293 Karar sayılı, 01.11.1982 tarihli kararında, “İdari işlemlerin hukuka aykırı bulunmaları halinde yapıldıkları tarihten geçerli olmak üzere geri alınmaları mümkün ise de; bu takdirde, işlemin yapıldı̆̆ tarihte yürürlükte olan yasalara uygun biçimde kazanılmış hakların korunması zorunlu olduğu gibi, geri alma işleminin makul bir süre içinde, hak ve nesafet kurallarını zedelemeyecek bir şekilde yapılması da gereklidir.” denilmiştir (Sever, 2006).

\section{AAD’nin İptal Nedenleri}

AAD işlemlerinin iptali istemleri, idari yargıda iki aşamada incelenmektedir. İlk olarak, yargı yerince açılan dava için ön koşullar incelemesi yapılmaktadır. Ön koşullar bakımından eksiği bulunmayan davada, bu kez, işlemin özüne (esasına) ilişkin inceleme yapılmaktadır. Bu aşamada, AAD işlemlerinin, hukuka aykırılık nedenleri ve hangi açılardan idari işlemin iptal edileceği incelenmektedir. Bu kapsamda, AAD işlemi ve dayanağı imar planı esas yönünden incelenebilmektedir. İşlemin esasına ilişkin incelemede, idari yargıda yetki, şekil, sebep, konu ve amaç yönlerinden yasanın öngördüğü koşulları taşımadığı saptanan işlem iptal edilmektedir.

Jeo. Jeolnf. Derg., 2020, 7(1):47-69 
AAD işlemi, hangi gerekçeler ile iptal edildi ise, idarenin mahkeme kararını uygularken bu gerekçeler dikkate alınmalıdır. Bu durum, Danıştay 1'inci Dairesi'nin 1999/15 Esas, 1999/23 Karar sayıl1, 05.02.1999 tarihli Kararında, “...ilgili yargı kararları istikrar kazanmış ise, her olayın özgün koşulları da dikkate alınmak suretiyle maddi ve hukuki olgularda farklılık olmaması halinde, emsal alınması gerekli nitelik taşırlar....Anayasanın 138 inci ve 2577 sayılı Idari Yargılama Usulü Kanununun 28 inci maddeleri uyarınca, karar gereklerine göre idare, işlem tesis etmeye mecbur olduğundan, istişari kararların niteliği gereği, yargı yerlerinde görülmekte olan ya da karara bağlanmış bulunan dava konularıyla ilgili olarak istişari görüş bildirilmesine olanak bulunmadı̆̆ı gibi, yargı yerlerince verilen bir kararın uygulanmasında düşülen duraksamanın giderilmesi amacıyla belirsiz ve açık olmayan yönlerini ya da birbirine aykırı hüküm fikralarını ortadan kaldırmak görev ve yetkisi, 2577 sayılı Kanunun 29 uncu maddesinde yer alan "Açıklama" hükümleri çerçevesinde kararı veren yargı yerine ait bulunmaktadır. ... Açıklanan nedenlerle... dava konusu benzeri olayların özgün koşulları da dikkate alınmak suretiyle idarece yargı kararları doğrultusunda işlem tesisi gerekeceği ... sonucuna ulaşılarak dosyanın Danıştay Başkanlığına sunulmasına karar verildiği” hüküm altına alınmıştır. Dolayısıyla, idari yargının her bir kararını kendi özelinde değerlendirmek ve sonuçlandırmak gerekmektedir (Köktürk, 2007).

\subsection{Yetki ve Şekil Yönleriyle}

Encümen kararındaki belirsiz ifadeler, parsellerin yanlış ya da eksik yazılması, gerekli onayların bulunmaması, işlemin malikine tebliğ edilmemesi gibi hususlar, AAD işlemindeki yetki ve şekil eksikliği olarak değerlendirilmektedir. İdareler, yetki ve şekil yönünden hatalı AAD işlemlerini, yeni bir encümen kararı alarak düzeltebilir.

Danıştay 6’ncı Dairesi'nin 1993/3010 Esas, 1994/2444 Karar sayıl1, 13.06.1994 tarihli “...davacı parselinin yazılmamış olması nedeniyle ortaya çıkan şekil noksanlığının daha sonra alınan encümen kararı ile giderilmiş olması ve uygulamada da 3194 sayılı İmar Kanunu’nun 18’inci maddesine uygun olarak işlemlere başlanılması karşısında, anılan madde uygulamasının hukuki dayanaktan yoksun olduğunun kabulüne hukuken imkan bulunmamaktadır....Bu durumda İdarelerin hatalı işlemlerini düzeltebileceği ilkesi ile yerinde yaptırllan keşif ve bilirkişi incelemesi sonucu düzenlenen rapordaki bulgular da gözetilerek yeniden bir karar verilmesi gerekmektedir.” kararında, yapılan parselasyon işleminde şekil eksikliği olması durumunda idarelerin hatalı işlemleri düzeltebileceği ilkesine yer verilmiştir.

Ayrıca, Tapu ve Kadastro Genel Müdürlüğü Tasarruf İşlemleri Dairesi Başkanlığı’nın (TİDB) 18.08.2000 tarihli ve 3429 sayılı talimatındaki; “...18'inci madde uygulamasl yapılan alanda, Yasaya aykırı olarak plân düzenleyen idarece bir maddi hata yapılmışsa, bu hatanın düzeltilmesi için plân değişikliğine gerek bulunmamaktadır. Belediyelerce, maddi hata yapıldı̆̆ının belirtilmesi halinde, alınacak encümen kararına istinaden Tapu ve Kadastroca gerekli düzeltme yapılabilir." hükmü ile maddi hataların encümen kararına binaen düzeltilebileceği belirtilmiştir (URL-10).

\subsection{Sebep, Konu ve Maksat Yönleriyle}

AAD’nin tamamının sebep, konu ve maksat yönlerinden iptal edilmesi, iptal kararının DOP alanlarını, geometrik biçim ve alan değişikliklerini içermesidir. İdari yargının hukuken verdiği iptal kararının gereği teknik olarak yerine getirilirken, iptal işleminden etkilenen parsellerin tümünde AAD işleminden önceki hukuki duruma (kadastral duruma), kök tapulara dönülmesi için çalışmalar yapılmaya başlanmalıdır. Hukuki dayanağı kalmayan ve bu sebeple yolsuz tescile dönüşen imar parsellerinin tapu kaydının iptali ile, AAD işlemi öncesi kadastral parsele/parsellere dönülmelidir.

Danıştay 6’ncı Dairesi'nin, 2004/1082 Esas, 2006/953 Karar, 08.03.2006 tarihli kararında, “...Parselasyon işleminin yargl kararıyla iptal edilmesi üzerine kök parsele dönülerek yargı kararının dikkate alınması suretiyle yeni parselasyon işleminin yapılması"; aynı Daire'nin 2004/8073 Esas, 2007/1098 Karar sayıl1, 23.02.2007 tarihli kararında, "Parselasyon işleminin yargı kararı ile iptali sonucunda iptal kararının gereğinin yerine getirilmesinin ilk koşulunun, ilgilisi açısından parselasyon 
öncesi hukuki duruma yeniden gelinmesininsağlanması olduğu, bu itibarla davalı idarece ileri sürülen hususların iptal gerekçeleri çerçevesinde irdelenmesi ve yargı kararının uygulanıp uygulanmadı̆̆ı hakkında bir karar verilmesi gerektiği” karara bağlanmıştır.

Yargitay 1'inci Hukuk Dairesinin 2014/1517 Esas, 2014/4385 Karar say1l1, 26.02.2014 tarihli “....imar parseli imar işleminin iptal edilmesi sebebiyle ortadan kalktığına göre öncelikle geri dönüşüm veya yeni bir imar uygulamast işleminin tamamlanıp tamamlanmadı̆̆ının araşttrılmasl, kadastral parsele geri dönüşüm veya yeni bir imar uygulaması işlemi tamamlanmış ise tecavüzün hangi kadastral veya imar parseli içerisinde kaldı̆ğ ve tecavüze konu bölümle ilgili davacının bir mülkiyet hakk olup olmadığının belirlenmesi; geri dönüşüm veya yeni bir imar uygulaması işlemi tamamlanmamıs ise sonucunun beklenmesi ve ondan sonra bir karar verilmesi gerekirken, hukuki dayanăğ kalmayan imar kaydı üzerinden yazılı biçimde hüküm kurulması doğru değildir." kararı ile 26.02.2014 tarihli ve 2004/488 Esas, 2004/1294 Karar sayıl1, 18.02.2004 tarihli “...Davaya konu edilen tapu kaydını oluşturan işlemin kesinleşen idari yargı kararıyla ortadan kaldırllması halinde, tapu kaydı kendiliğinden hükümsüz hale gelmez. Kesinleşen bu idari karar, ilgilisine kadastral sicilin ihyası (kadastral duruma dönülmesi) için talep ve dava hakkı verir. Bu durumda hukuki dayanağı kalmayan ve bu sebeple yolsuz tescil niteliğini taşıyan imar parsellerinin tapudaki kaydının iptali ile imar öncesi kadastral parsele dönüștürülmesi” kararına göre hukuki dayanağ 1 kalmayan ve bu sebeple yolsuz tescile dönüşen imar parsellerinin tapu kaydının iptali ile AAD işlemi öncesi kadastral parsele/parsellere dönülmelidir.

\section{Geri Dönüşüm İşlemleri}

Sebep, konu ve maksat yönlerinden iptal edilen, hukuki dayanağı kalmayan, bu sebeple yolsuz tescile dönüşen imar parsellerinde geri dönüşüm işlemleri gerçekleştirilmelidir. İdari yargı tarafından iptal edilen AAD işleminin hiç yapılmamış kabul edilmesi; yasa, yönetmelik, Danıştay ve Yargıtay içtihatlarının ve idare hukukunun bir gereğidir.

Bu konuda, son yapılan değişiklerle 3194 sayılı İmar Kanunu ve Arazi ve Arsa Düzenlemeleri Hakkında Yönetmelik’e yeni hükümler getirilmiştir. 3194 sayılı İmar Kanunu'nun Arazi ve Arsa Düzenleme Esasları başlıklı Üçüncü Bölümü’nde belirtilen 18. maddenin 19. fikrasında ve Resmi Gazete'de 22.02.2020 tarihli ve 31047 sayı ile yayımlanarak yürülüğe giren Arazi ve Arsa Düzenlemeleri Hakkında Yönetmelik’in Altıncı Bölümü’nün 37. ve 38. maddelerinde geri dönüşüm işlemleri anlatılmaktadır.

Mahkeme tarafından verilen iptal kararının ilgili idare tarafından yerine getirilmesi iki şekilde olabilir:

- İptal kararına konu veya iptal kararından etkilenen imar parselleri için geri dönüşüm cetvelleri düzenlenerek, imar parsellerini AAD işlemi öncesi mülkiyet durumuna çevirmek,

- İptal kararına konu veya iptal kararından etkilenen imar parselleri için hem geri dönüşüm cetvelleri düzenleyerek hatalı işlemi geri almak hem de geri dönüşüm çalışması ile birlikte eş zamanlı olarak yeni bir AAD işlemi yapmak.

İdari yargının iptal kararının uygulanması ile ilgili yasal düzenleme bulunmadığından, geri dönüşüm işlemlerine yargı kararlarına bağlı olarak şekillenmiş Danıştay ve Yargıtay içtihatları yön vermektedir. Geri dönüşüm işlemleri, geri dönüşüm işleminden sonra yeni bir AAD işlemi yapılmayacak olsa bile, yetkide ve usulde paralellik ilkesi gereği iptal edilen AAD işleminin tesisindeki usul ile aynı olmalıdır. Yetki ve usulde paralellik ilkesi, idare hukukuna ilişkin herhangi bir mevzuatta yer almamakla birlikte içtihatlarla geliştirilen önemli ilkelerdendir (Aky1lmaz, 2000). Danıştay 5'inci Dairesi'nin 1992/5775 Esas, 1993/3756 Karar sayılı, 13.10.1993 tarihli kararında, "Yasada aksine bir düzenleme bulunmadıkça idare hukukunun 
önemli ilkelerinden birisi olan yetki ve usulde paralellik ilkesi uyarınca bir işlemin tesisinde uygulanan yetki ve usul koşullarının aynı işlemin geri alınması, kaldırılması işlemlerinde ve tersi işlemin yapılmasında da aynen uygulanması zorunludur. İdareye tanınan bu takdir yetkisinin ise kamu yararı ve hizmet gerekleri gözetilerek kullanılabileceği ve bu yetkiye dayanılarak yapılan işlemlerin de bu açıdan yargı denetimine tabi bulunduğu yine idare hukukunun bilinen ilkeleri arasında yer almaktadır." denilmektedir.

Geri dönüşüm işlemlerinde izlenecek yol, Şekil 1'de gösterilmiştir. Bu sureçte yapılacak işlemler; (1) genel işlemler, (2) AAD sonrasında bölgede ya da parsellerde, mülkiyet ve/veya zemindeki fiili durum yönünden bir değişiklik yaratan işlemler olarak sınıflandırılıp yargı kararları ışığında aşağıdaki bölümlerde incelenmiştir.

\subsection{Genel İşlemler}

\subsection{1 İdari İşlemler}

\section{Mahkeme Kararının Tebliğinden İtibaren 30 Gün İçinde İptal Kararının Uygulanması}

2577 sayılı İdari Yargılama Usulü Kanunu'nun 28'inci maddesi gereğince; mahkeme kararının tebliğinden itibaren 30 gün içinde idarelerin, mahkeme kararının gerekçelerine göre, işlem yapmaları mecburidir. Ancak, askı ilan sürecinin bile 30 gün olduğu göz önünde bulundurulduğunda tüm işlemlerin 30 günde yetişmesi mümkün değildir. Bu sebeple, AAD işleminin iptali yolunda verilen karardan sonra, idarenin söz konusu işi yapma konusunda iradesini belirtmesi bakımından encümen kararını (idarenin onay kurulu kararını) alıp tapuya bildirmesi, devamında makul bir süre içinde yeniden bir AAD işlemi tesis etmesi gerekmektedir (Koçak \& Beyaz, 2015). İdare iyi niyetli olarak bölgenin büyüklüğü, teknik ve hukuki zorluklarına göre en kısa sürede hatalı işlemi geri almalıdır. Bu durum, Danıştay 6’ncı Dairesi'nin 1998/4313 Esas, 1999/4953 Karar sayılı, 19.10.1999 tarihli kararında, “...Davacının taşınmazını da kapsayan alanda yapılan parselasyon işleminin iptali yolunda verilen karardan sonra makul bir süre içinde yeniden bir parselasyon işlemi tesis edilmesi gerektiğinden..." hükmü ile ifade edilmiştir.

\section{AAD'nin İptal Kararının İdarece Yerine Getirilmesi Mecburiyeti}

Türkiye Cumhuriyeti Anayasası'nın 138'inci maddesinin son fikrası, “Yasama ve Yürütme Organları ile idare, mahkeme kararlarına uymak zorundadır; bu organlar ve idare, mahkeme kararlarını hiçbir suretle değiştiremez ve bunların yerine getirilmesini geciktiremez..." gereğince idarelerce mahkeme kararlarının yerine getirilmesi zorunluluktur. İptal edilen AAD işleminin hukuk sisteminde yeri olamayacağından, sonuçlarının mümkün olduğunca silinmesi ve AAD işlemi öncesi mülkiyet yapısına dönülmesi gerekmektedir. Bu durumda, idarelerin mahkeme kararlarını uygulamama gibi bir keyfi durumları veya yetkileri bulunmamaktadır.

Danıştay 6'ncı Dairesi'nin 1995/7076 Esas, 1996/4029 Karar sayıl1, 09.10.1996 tarihli kararına göre, “İdare Mahkemesince, 2577 sayıl Yasanın 28'inci maddesinin 3'üncü fikrasına göre, idare mahkemesince verilen yürütmenin durdurulması kararına göre işlem tesis edilmeyen veya eylemde bulunulmayan hallerde idare aleyhine maddi ve manevi tazminat davası açılabileceği, ... Yürütmenin durdurulması kararı da Anayasa'da ve İdari Yargılama Usulü Yasasında belirtilen nitelikte bir yargı kararı olduğuna göre, bu yolda karar verilmiş bir davada idarenin; esas kararın verilmesini, bu karar temyiz edilmiş veya kararın düzeltilmesi yoluna başvurulmuş ise verilecek kararı beklemesi, bu yolla, verilen yürütmenin durdurulması kararını sürüncemede bırakması, savsaklaması ve etkisiz kılması gibi seçeneği bulunmamaktadır...Bir Hukuk Devletinde aslolan idarenin yargı kararını kendiliğinden uygulamasıdır... Öte yandan, yargı kararlarının uygulanmamasının hem bir iptal nedeni hem de ă̆ır hizmet kusuru oluşturduğu açıktır." idari yargı kararının karşısında, yöneticilerin takdir yetkileri bulunmamaktadir. 
İdarenin yargı kararlarına uymak ve bu kararların gereklerine göre işlem yapmak ya da eylemde bulunmak zorunda olması, aynı zamanda “hukuk devleti” ilkesinin de bir gereğidir. Danıştay 1'inci Dairesi'nin 1984/221 Esas, 1984/218 Karar sayılı, 05.10.1984 tarihli kararına göre, idarelerin, “...yargı kararları doğrultusunda işlem tesis etmeleri...” gerekmektedir. Yargıtay 1 'inci Hukuk Dairesi'nin 2004/11454 Esas, 2004/12516 Karar sayıl1, 04.11.2004 tarihli kararına göre, “Yargı mercilerince verilen kararlar, yöntemine uygun biçimde kesin hüküm niteliğini kazandı̆̆ında "Lazım-ül icra" (uygulanması gereken) duruma gelirler.” denildiğinden iptal kararının idarelerce uygulanması gerekmektedir.

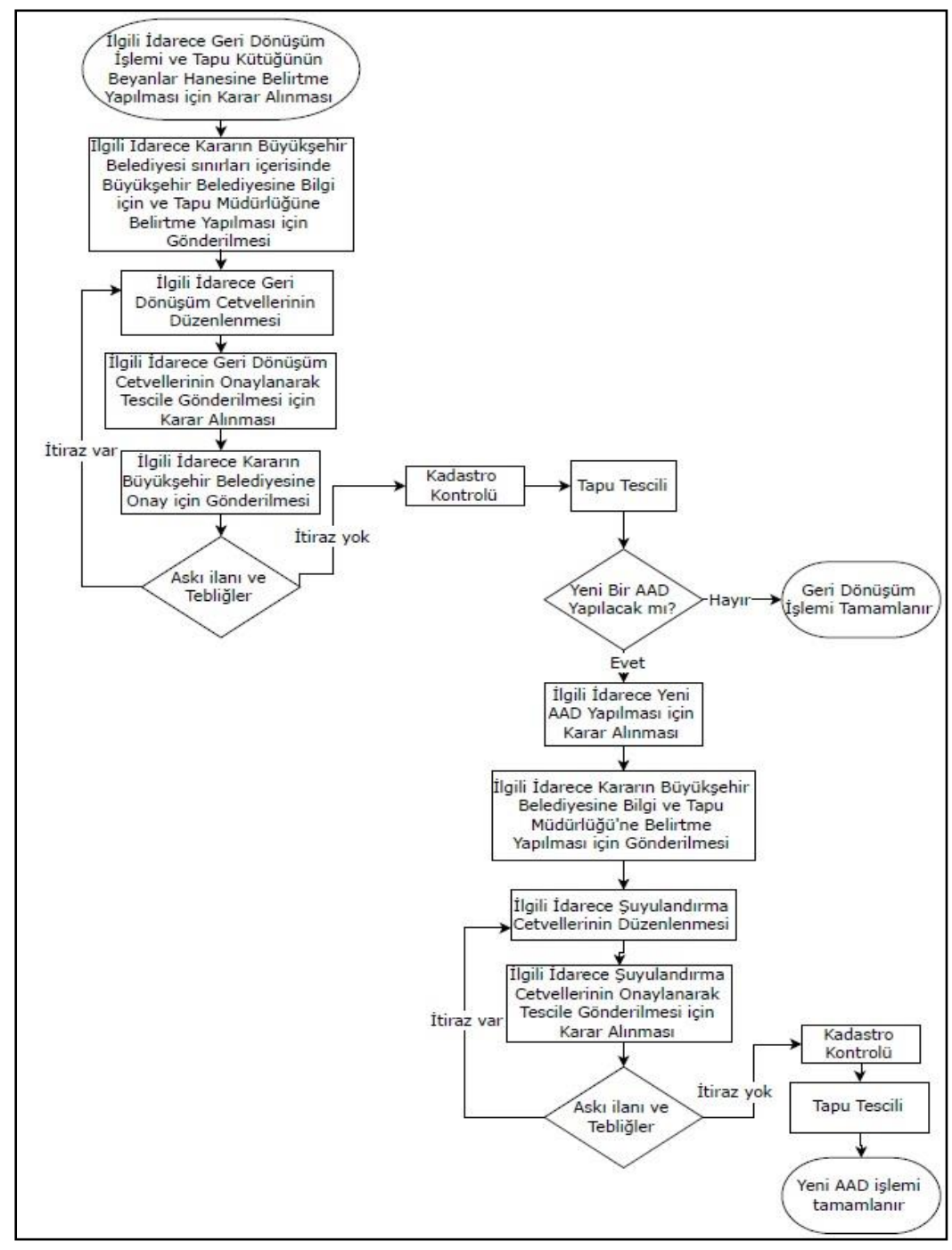

Şekil 1: Geri dönüşüm işlemi (Hacıosmanoğlu, 2019)

\section{İdarenin Onay Kurulu Kararının 2981 Sayılı Kanun'un 10'uncu Maddesinin (b) Bendine Göre Alınmış OIması Durumunda Geri Dönüşüm}

Belediyeler, 2981 sayılı Yasanın 10'uncu maddesinin (b) bendi uyarınca 1slah imar planı uygulaması yapma ve onama yetkisine sahip değildir. Anılan maddeye göre işlem yapılmasını, ancak kadastro müdürlüklerinden isteyebilirler. Bu durumda, AAD'nin 2981 sayılı Yasanın 10'uncu maddesinin (b) bendine göre onaylandığının belirtilmesi, hem 2981 sayılı Kanun'un 10'uncu maddesi hem de Danıştay kararına aykırıdır. Danıştay 6’ncı Dairesi’nin, 1998/724 Esas, 1999/563 Karar sayılı, 04.02.1999 tarihli kararında, “Belediyelerin 2981 sayılı yasanın 10/b maddesi uyarınca parselasyon işlemi yapma

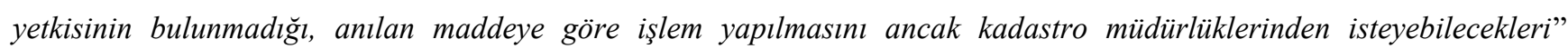
belirtilmiştir. 


\section{AAD İşlemi Parsel Bazında Sebep, Konu ve Maksat Yönlerinden İptal Edilmişse Yapılması Gerekenler}

Davacı tarafından, AAD işleminin yalnızca kendi taşınmazıyla ilgili kısmının iptali istenmişse veya yargı yeri tarafından, AAD işleminin davacı taşınmazına yönelik kısmının iptaline karar verilmişse, davacı taşınmazının bulunduğu kısmın yeniden uygulamasının yapılması suretiyle ilam yerine getirilmiş olur. Başka bir ifade ile davacı taşınmazının durumu, yargı kararının gerekçesinde belirtilen hale getirilir. Bu işlemler yapılırken, birinci AAD işlemini yapan idarece iptal kararına uygun olarak kadastral parsellere dönülmeksizin ikinci AAD işlemi uygulanmalıdır (Ergen, 2006).

\section{İmar Planı İptallerinde AAD'nin de İptal Olup Olmayacağı}

İdari yargıya verilecek dava dilekçesinde, AAD işleminin yanı sıra, imar planının da incelenmesi istenmelidir. Çünkü, AAD işlemi hukuka uygun, ancak dayanağı imar planı hukuka aykırı ise AAD yine iptal edilmekten kurtulamaz. AAD’ye karşı açılan davada, imar planının iptali unutulur veya istenmezse dava yalnızca arsa düzenlemeleri bakımından görülür (Köktürk, 2009).

Danıştay’ın, “Imar uygulamasına karşı açılan davada, iptali istenilmeyen imar planının incelenemeyeceği; dava konusu olmadı̆̆ halde imar planına yönelik dĕgerlendirmeleri esas almak suretiyle parselasyon işleminin iptaline karar verdiğ $i$ anlaşılmaktadır. Bu durumda, parselasyon işleminin dayanağı 1/1000 ölçekli uygulama imar planı dava konusu edilmediğinden, dava konusu parselasyon işleminin yukarıda anılan Yasa ve Yönetmelik hükümleri ile 1/1000 ölçekli uygulama imar planına ve parselasyon ilkelerine uygun yapılıp yapılmadığının irdelenmesi suretiyle yeniden bir karar verilmelidir." hükümleri uyarınca, imar planı talep edilmeyen davalarda yalnızca AAD işlemi bakımından irdelenmek suretiyle karar verilmesi gerektiği; “imar planı ile ilgili kararın sonucuna göre parselasyon konusunda karar verilmesi gerektiği” hükmü ile hukuka aykırı imar planının iptali halinde, bu imar planına göre yapılan AAD işleminde de hukuka uyarlık bulunmadığı açıklanmıştır (Ergen, 2006).

Plan iptali, kamusal donatıların yol, yeşil alan, otopark gibi geometrik biçimi ve alanını değiştirmek konusunda ise, yeni plana göre imar parselleri üzerinden yeniden ikinci bir AAD işlemi yapılmalıdır. Ancak, iptal nedeni yalnızca imar hakkı ve yapı düzeni ile ilgili ise yeniden uygulama yapmaya gerek yoktur (Çelik, Uzun, Demir, \& Nişancı, 2000). Bu durum, Danıştay 6’nc1 Dairesi'nin 1999/3994 Esas, 2000/5332 Karar sayılı, 24.10.2000 tarihli kararında, "Yolların planlama ilkelerine uygunluğunun denetimi için, ulaşım sistemi, planlama alanında yoğunluk, topoğrafik yapı, kentsel fonksiyonlara erişim kolaylığı gibi hususlar ve kamu yararına göre inceleme yapılmasl gerektiği, bunların haricinde sadece mülkiyet durumuna göre değerlendirme yapılamayacă̆l, kaldırılan yeşil alana karşılık eşdeğer alan ayrılmadı̆̆l, imar planı ile ilgili kararın sonucuna göre parselasyon konusunda karar verilmesi gerektiği ” hükmü ile açıklığa kavuşturulmuştur.

\section{İdarelerin Geri Dönüşüm İşleminden Sonra Yeni Bir AAD Yapma Mecburiyeti Olup Olmadığı}

İdarenin görevi, iptal edilen AAD işleminin tüm hukuki sonuçlarını bir an evvel ortadan kaldırmak ve düzenleme öncesine geri dönmek için işlem tesis etmektir. Ardından mümkünse yeni bir AAD işlemi tesis edilmelidir. İmar uygulamalarını belediyeler mali olanaklarını gözeterek yasa gereği belirli bir mali program çerçevesinde gerçekleştireceğinden, bu konuda herhangi bir zorunlulukta bulunulamayacağı Danıştay 6’ncı Dairesi'nin 1994/4947 Esas, 1995/1985 Karar sayıl1, 27.12.1995 tarihli kararı ile hüküm altına alınmıştır.

Tapu ve Kadastro Genel Müdürlüğü talimatları, AAD’nin yargı tarafından iptal edilmesine kadar geçen süre zarfında zeminde fiili yapılaşma söz konusu olduysa, geri dönüşümün yanı sıra yeni bir imar uygulamasının da beraberinde yapılması yönündedir. İlgili idarenin bu talimata uygun hareket etmesi, hem idare hem de tapu müdürlüğü açısından uygulama kolaylı̆̆ı sağlayacaktır (URL-8). 


\subsubsection{Teknik İşlemler}

\section{Geri Dönüşüm İşlemi Yapmadan, Mevcut İmar Parselleri Üzerinden Yeni Bir Uygulama Yapılıp Yapılamayacağı}

Danıştay ve Yargıtay, iptal edilen AAD işlemi sonrası yeni yapılacak AAD’nin, iptal edilen AAD işlemi ile oluşan imar parselleri (yolsuz tescile dönüşen kayıtlar) üzerinden değil, AAD işlemi öncesi kadastral duruma dönülerek oluşacak kadastral parsellere göre yapılması gerektiğini açıklamıştır. İlk olarak anayasanın 138'nci maddesinin bir gereği olarak mahkeme kararının yerine getirilmesi amacıyla geri dönüşüm işlemi yapılarak kök parsel/parsellere dönülmesi, sonrasında yeni bir AAD işlemi yapılması uygundur.

Bu durum, Danıştay 6'ncı Dairesi'nin 2002/2368 Esas, 2003/5127 Karar sayıl1, 24.10.2003 tarihli kararında, “...parselasyon işleminin mahkemece iptal edilmesi halinde, düzenlemenin yapıldı̆̆ bölgede kadastral mülkiyete dönüş sağlanmış olacă̆ından, yeni yapılan düzenlemenin kadastral durum dikkate alınmak suretiyle yapılması gerekirken, iptal edilen düzenlemede yer alan parseller üzerinden yapılan düzenlemede mevzuata uyarlık bulunmadı̆̆g” hükmü ile açıklanmıştır. Aynı konuda, Yargıtay 1'inci Hukuk Dairesi’nin 2005/14270 Esas, 2006/2701 Karar sayıl1, 17.03.2006 tarihli ve 2004/2524 Esas, 2004/3027 Karar sayılı, 17.03.2004 tarihli kararında, “...Dava, tapu iptal ve tescil isteğine ilişkindir. Imar öncesi kadastral parsellerdeki hak durumu dikkate alınarak bir hüküm kurulması gerekirken, dayanağl ortadan kalkan ve geçerliliğini yitiren imar parseli üzerinden karar verilmiş olması doğru değildir.” hükmü verilmiştir.

Danıştay 6'ncı Dairesi'nin, 2004/1082 Esas, 2006/953 Karar sayı11, 08.03.2006 tarihli kararına göre, “...Parselasyon işleminin yargı kararlyla iptal edilmesi üzerine kök parsele dönülerek yargı kararının dikkate alınması suretiyle yeni parselasyon işleminin yapılması"; aynı Daire'nin 2004/8073 Esas, 2007/1098 Karar sayıl1, 23.02.2007 tarihli kararına göre, “...Parselasyon işleminin yargı kararı ile iptali sonucunda iptal kararının gereğinin yerine getirilmesinin ilk koşulunun, ilgilisi açısından parselasyon öncesi hukuki duruma yeniden gelinmesinin sağlanması olduğu, bu itibarla davalı idarece ileri sürülen hususların iptal gerekçeleri çerçevesinde irdelenmesi ve yargı kararının uygulanıp uygulanmadı̆̆ı hakkında bir karar verilmesi gerektiği”" hükümleri gereğince de parselasyonun yargı kararı ile iptali sonucunda ilgilisi açısından parselasyon öncesi hukuki duruma gelinmesi sağlanmalıdır. Yargıtay 1'inci Hukuk Dairesi'nin 2014/1517 Esas, 2014/4385 Karar sayılı, 26.02.2014 tarihli “....imar parseli imar işleminin iptal edilmesi sebebiyle ortadan kalktı̆̆ına göre öncelikle geri dönüşüm veya yeni bir imar uygulaması işleminin tamamlanıp tamamlanmadığının araştırılması, kadastral parsele geri dönüşüm veya yeni bir imar uygulaması işlemi tamamlanmış ise tecavüzün hangi kadastral veya imar parseli içerisinde kaldığı ve tecavüze konu bölümle ilgili davacının bir mülkiyet hakkı olup olmadığının belirlenmesi; geri dönüşüm veya yeni bir imar uygulaması işlemi tamamlanmamış ise sonucunun beklenmesi ve ondan sonra bir karar verilmesi gerekirken, hukuki dayană̆ı kalmayan imar kaydı üzerinden yazılı biçimde hüküm kurulması doğru değildir.”; 26.02.2014 tarihli ve 2004/488 Esas, 2004/1294 Karar sayılı, 18.02.2004 tarihli “...Davaya konu edilen tapu kaydını oluşturan işlemin kesinleşen idari yargı kararıyla ortadan kaldırılması halinde, tapu kaydı kendiliğinden hükümsüz hale gelmez. Kesinleşen bu idari karar, ilgilisine kadastral sicilin ihyası (kadastral duruma dönülmesi) için talep ve dava hakkı verir. Bu durumda hukuki dayană̆ kalmayan ve bu sebeple yolsuz tescil niteliğini taşlyan imar parsellerinin tapudaki kaydının iptali ile imar öncesi kadastral parsele dönüşı̈̈rülmesi" hükümlerine göre de, hukuki dayanağı kalmayan ve bu sebeple yolsuz tescil niteliğini taşıyan imar parsellerinin tapudaki kaydının iptali ile imar öncesi kadastral parsele dönüştürülmelidir.

\section{Bağışların ve Rızai Terklerin Geri Dönüşümü}

İptal edilen AAD'de yapılan bağışların ve rızai terklerin geri dönüşümüne, şartlı yapılıp yapılmadıklarına göre karar verilmektedir. İptal edilen AAD'de bağışlanan yer bağışlama amacı dışına çıkmışsa, bu durumda bağış miktarı bağışlayana geri dönmelidir (URL-7). AAD iptal edilene kadar geçen süre zarfında yapılan terk miktarlarının geri dönüşümünde terkin 
şartlı yapılıp yapılmadığı esasına göre karar verilmelidir.

Anayasa Mahkemesi'nin 12.01.2012 tarihli ve 2011/23 Esas, 2012/3 Karar sayılı kararında, “Malikin rızasıyla yola terk etmesi de kaynaklardan birisi olmakla birlikte bu durumda bir bă̆ışlama söz konusu olup hukukumuzda bă̆lşlamanın şarta bağlı olarak yapılması mümkündür. Ĕ̆er malik bă̆ışladığ taşınmazın yol dışında başka bir amaç için kullanılmasını istemiyorsa şarta bağlı bağışlama yapma imkânına sahiptir." hükmü verilmiştir. Bu hükümle, şartlı bağış yapılabildiğine; rızai terk miktarlarının da bağış kapsamında sayıldığına; bu suretle, geri dönüşüm işlemlerinde şartlı bağış yapılıp yapılmadığı durumuna göre bir karar verilmesi gerektiğine; olayda şarta bağlı bağışlama söz konusu ise bağışlanan alanın amacı dışına çıkması durumunda bağışlayana geri dönmesi gerektiğine hükmedilmiştir.

\section{Kamusal Ortaklık Payına Giden Kısmın Geri Dönüşümü}

KOP'a giden hisse, ilgilisi feragat etmedikçe ya da ilgili idare tarafından kamulaştırılmadıkça, o kişi adına tescilli olmaya devam edecektir. Eğer AAD işlemi iptal edilmişse, KOP’a giden kısım da malikine geri döner (Çelik vd., 2000).

\section{Geri Dönüşüm Hesapları ile Kadastral Parseldeki Yüz Ölçümün Uyuşmaması Durumunda Geri Dönüşüm}

Geri dönüşüm çalışması, AAD işleminin yargı kararı ile iptal edilmesi nedeniyle gerçekleştirildiğinden, söz konusu AAD işleminin hiç yapılmamış sayılması gerekmektedir. Bu nedenle, AAD işlemi öncesi parsel yüz ölçümü doğrudan geri dönüş yüz ölçümü olarak kaydolmalıdır.

\subsubsection{Hukuki İşlemler}

\section{İkinci AAD İşlemi Yapılması Koşulları}

AAD işlemi yapılmış bir yerde ikinci kez veya daha fazla AAD işlemi yapılabilmesi ve şuyulandırma cetvellerinin değiştirilebilmesi için geçerli bir hukuki sebep olmalıdır. Danıştay 6'ncı Dairesi'nin 2006/991 Esas, 2008/968 Karar sayılı, 15.02.2008 tarihli kararında, "imar planı değişikliği suretiyle, yeni bir düzenleme yapılmasını gerektirecek bir neden ortaya konulmaksızın, aynı bölgede üçüncü kez imar uygulaması yapılmasında, hukuka uygunluk bulunmadı̆̆ı" açıklanmıştır. Danıştay 6’ncı Dairesinin 1999/1215 Esas, 2000/1847 Karar sayıl1, 04.04.2000 tarihli kararında, “imar planı ile yeni bir düzenleme yapılmasını gerektirecek bir neden olmaksızın ikinci kez parselasyon yapılmasına imar hukukuna uyarlık bulunmadı $\breve{l} \iota "$ hükmü verilmiştir.

AAD işleminin mahkeme kararıyla iptal edilmesi, yeni bir AAD işlemi yapılması için geçerli hukuki sebeplerden biridir. 4721 sayılı Türk Medeni Kanunu'nun 1027'nci maddesine göre, tapu kütüğünde düzeltme yapılması koşulla sınırlandırılmıştır: "İlgililerin yazılı rızaları olmadıkça, tapu memuru, tapu sicilindeki yanlışlı̆̆g ancak mahkeme kararıyla düzeltebilir. Düzeltme, eski tescilin terkini ve yeni bir tescilin yapılması biçiminde de olabilir...”. AAD yapılmış bir yerde,

- İdari yargıda verilmiş imar planının ya da AAD’nin iptal kararı bulunması,

- İmar planında değişiklik olması

durumları ikinci kez AAD işlemi yapılması koşullarıdır.

Ayrıca, 3194 sayılı İmar Kanunu'nun 18'nci maddesinin 7'nci fikrasında, “(Değişik fikra:4/7/2019-7181/9 md.) Bu madde hükümlerine göre, herhangi bir parselden bir defadan fazla düzenleme ortaklık payı alınmaması esastır. Ancak, her türlü imar planı kararı ile yapılaşma koşulunda ve nüfusta artış olması hâlinde, artış olan parsellerden, uygulama sonucunda oluşan dĕgerinin önceki değerinden az olmaması kaydıyla, ilk uygulamadaki düzenleme ortaklık payı oranını \% 45 'e kadar 
tamamlamak üzere ilave düzenleme ortaklık payı kesintisi yapılabilir." şeklinde yapılan değişiklikle, her türlü imar planı kararı ile yapılaşma koşulunda ve nüfusta artış olması hâlinde, artış olan parsellerden, uygulama sonucunda oluşan değerinin önceki değerinden az olmaması kaydıyla, ilave düzenleme ortaklık payı kesintisi yapılabileceği belirtilmiştir.

\section{İdarece İptal Kararının Gereği Yapılmazsa İlgilisince Yapılacak İşlem}

AAD işleminin iptal kararı işlemi yapan idareye tebliğ edilmesine karşın ilgili idarece işlem yapılmazsa, AAD işlemini iptal ettiren davacı, idare mahkemesinin iptal kararını gerekçe göstererek asliye hukuk mahkemesinde tescil iptal davası açarak mevcut tescili iptal ettirebilir.

Danıştay 6'ncı Dairesi'nin 19.01.2009 tarihli ve 2008/8952 Esas, 2009/406 Karar sayılı kararı ile “KARAR : Dava, Bursa, Yıldırım, Selimzade Mahallesi, H22d07b.4a pafta, 4141 ada, 1 ila 8 sayılı parseller ile 4115 ada, 1 parsel sayılı taşınmazları kapsayan alanda, 3194 sayılı Kanun'un 18'inci maddesi uyarınca yapılan imar uygulamasının Bursa 2'nci İdare Mahkemesi'nin 6.2.2006 günlü, E:2005/473, K:2006/146 sayılı kararıyla iptal edildiğinden bahisle eski duruma dönülmesi yolunda işlem tesis edilmesi istemiyle yapılan başvurunun reddine ilişkin 2.4.2007 günlü, 111/518 sayılı işlemin iptali istemiyle açılmış; Idare Mahkemesi'nce, olayda parselasyon işleminin yargı kararı ile iptali sonucunda iptal kararının gereğinin yerine getirilmesinin ilk aşaması eski parsellere dönüş cetvellerinin hazırlanması, onanması ve tapu kayıtlarında değişiklik olmuşsa eski hale dönüş yapılarak, ilgilisi açısından parselasyon öncesi hukuki duruma yeniden gelinmesinin sağlanması gerekirken, bu doğrultudaki başvurunun reddi yolunda tesis edilen dava konusu işlemin hukuka aykırı olduğu gerekçesiyle iptaline karar verilmiş, bu karar davalı tarafından temyiz edilmiştir.

SONUÇ : Dava konusu işlemin yukarıda özetlenen gerekçeyle iptali yolundaki temyize konu Bursa 3'üncü İdare Mahkemesi'nin 13.5.2008 günlü. E:2007/1432, K:2008/345 sayılı kararında, 2577 sayılı İdari Yargılama Usulü Kanunu'nun 49'uncu maddesinin 1'inci fikrasında sayılan bozma nedenlerinden hiçbirisi bulunmadı̆̆ından, bozma istemi yerinde görülmeyerek anılan mahkeme kararının ONANMASINA, dosyanın adı geçen mahkemeye gönderilmesine, 19.01.2009 gününde oybirliğiyle karar verildi.” denilmek suretiyle, ilgilisinin idari yargının iptal kararı sonrası işlemin düzeltilmesine yönelik idareye yaptığı başvurunun reddine ilişkin konuyu Danıştay dairesine taşıması sonucu davacı istemi yerinde görülerek idare mahkemesinin kararı onanmıştır (Akış, 2014).

Yargıtay 1'inci Hukuk Dairesi'nin 29.04.1993 tarihli ve 1993/866 Esas, 1993/5535 Karar say1lı kararında, “...şuyulandırmaya ilişkin tapunun idari yargı kararı ile iptal edilmiş olması durumunda, idari karar asıl tapu kaydını kendiliğinden geçersiz hale getirmez. Bu karar ilgilisine kadastral duruma dönülmesi için istek ve dava hakkı verir.”; Yargitay 1'inci Hukuk Dairesi'nin 1997/4601 Esas, 1997/5035 Karar say1l1, 14.04.1997 tarihli kararında, “Dayanılan tapu kaydını oluşturan işlemin, kesinleşen idari yargı kararı ile ortadan kaldırılması halinde, tapu kaydı kendiliğinden hükümsüz hale gelmez. Kesinleşen bu idari yargı kararı ilgilisine kadastral sicilin ihyası için talep ve dava hakkı verir. " hükümleriyle ilgilisinin asliye hukuk mahkemesinde açacağı bir dava ile düzenleme öncesi mülkiyetin ihyasını talep edebileceği karara bağlanmıştır. Danıştay 6’ncı Dairesi'nin 1995/7076 Esas, 1996/4029 Karar sayılı, 09.10.1996 tarihli kararında, “davacı da kararın uygulanması için idareye başvurabilir. Bu başvurunun reddedilmesi halinde İdare Hukuku bakımından tek yanlı irade beyanı içeren ve ilgili hakkında hukuki sonuç yaratan bir işlem tesis edilmiş olacağından bu işleme karşı iptal davası açılabileceği kuşkusuzdur." denilmiştir.

Danıştay ve Yargıtay kararları incelendiğinde; mahkemenin iptal kararının uygulanabilmesi için;

- İlgilisi, AAD işlemini yapan idareye başvurarak iptal edilen AAD işlemi öncesi kadastral duruma dönülmesini talep edebilir. 
- İdarenin talep üzerine işlem yapmaması durumunda, ilgilisi mahkemenin iptal kararını gerekçe göstererek, asliye hukuk mahkemesinde tescil iptal davası açılabilir.

İlgilisi davayı kazanırsa, kendisi hakkında olan tescili iptal ettirebilir. Böylece asliye hukuk mahkemesinin kararına binaen tapu müdürlüğünce işlem yapılabilir. Yapılan işlemlerle ilgili uygulayıcı kuruluşa bilgi verilir (Koçak \& Beyaz, 2015). Davacının parseli dışında idari yargının iptal kararından etkilenen parseller var ise; bunlarla ilgili yapılan düzeltme işlemi, Türk Medeni Kanunu’nun 1019'uncu maddesi gereğince ilgililerine bildirilir.

\section{İptal Kararı Gereğince Tapu Müdürlüğünce İşlemin Düzeltilip Düzeltilemeyeceği}

Mahkemenin iptal kararı gereğince tapu kütüğünde yolsuz tescil durumuna düşen tapu kayıtları, ilgili idare tarafından yeni bir AAD işlemi yapılmadığı sürece, kendiliğinden düzeltilemez. Tescil edilmiş bir ayni hakkı, tapu müdürlüklerinin kütüklerinden silme veya düzeltme yetkisi bulunmamaktadır. İptal kararının gereğini AAD işlemini yapan idarenin yapması uygundur. Yargitay 1'inci Hukuk Dairesi'nin 2014/1517 Esas, 2014/4385 Karar sayıl1, 26.02.2014 tarihli kararında, “Bilindiği üzere, tapu kaydının illeti ve sebebi sayılan idari işlemin iptal edilmesi halinde, bu suretle oluşan kayıtların yolsuz tescil durumuna düşeceği, öte yandan idari işlemi iptal eden İdari Yargı kararının niteliği itibariyle önceki kayıtları kendiliğinden ihyâ etmeyeceği kuşkusuzdur." şeklinde ifade edilmektedir.

\subsection{AAD Sonrasında Bölgede ya da Parsellerde, Mülkiyet ve/veya Zemindeki Fiili Durum Yönünden Bir Değişiklik Yaratan İşlemler}

\subsubsection{Teknik İşlemler}

\section{İptal Edilen AAD ile Oluşan Parsellerin EI Değiştirerek Üçüncü Kişilerin Mülkiyetine Geçmesi Durumunda Geri Dönüşüm (Malik Değişikliği/Hak Değişikliği Durumunda Geri Dönüşüm)}

İptal edilen AAD işlemi ile oluşan parselin el değiştirmesi geri dönüşüm ve geri dönüşüm sonrası yeni bir AAD işlemi yapılmasına engel değildir. Cebr-i satış, satış, intikal gibi mahkeme kararı ile el değiştiren taşınmazlar iyi niyetli halefiyet kuralları gereği son halef adına tapuda tescil edilmelidir. Bu doğrultuda Yargıtay 1'inci Hukuk Dairesi’nin 2006/3554 Esas, 2006/4865 Karar sayılı 27.04.2006 tarihli kararında, “...Davacıların isteği, idari yargl yerinde iptal edilen önceki imar uygulaması sonucu ortaya çıkan durum nedeniyle imar öncesi kadastral hak durumuna dönülmesine dairdir. Açıklanan işleyişs içerisinde davacıların 2524 ada 15 kadastral parseldeki haklarını satış yoluyla edindikleri paydaşların haklarına halef olarak önceki kadastral parsel mülkiyet durumuna dönülmesini istemekte haklarl olduğu düşünülmelidir.” hükmü verilmiştir (URL-9).

\section{İptal Edilen AAD ile Oluşan Parsellerin El Değiştirerek Üçüncü Kişilerin Mülkiyetine Geçmesi Durumunda Düzenleme Ortaklık Payına Giden Kısımların Geri Dönüşümü}

İmar parseli el değiştirmişse, eski malik tüm haklarını devretmiş olduğundan, DOP miktarı da eklenmek suretiyle kadastral parseldeki hak yeni malik adına dönmelidir.

\section{İptal Edilen AAD ile Oluşan Parsellerde Kat Mülkiyeti/Kat İrtifakı Tesis Edilmiş İse Geri Dönüşüm}

AAD işleminin iptali halinde uygulama imar planına uygun olarak verilen yapı ruhsatlarının iptalinin gerekmeyeceği, ancak yeni AAD’ye göre bu yapıların ruhsata bağlanması mümkün değilse, kazanılmış haklar gözetilerek bu aşamadan sonra inşaat ruhsatlarının iptali söz konusudur. Bu durum, Danıştay 6'ncı Dairesi'nin 2003/3434 Esas, 2004/6885 Karar sayılı, 22.12.2004 tarihli kararında, “Arsa düzenlemesi iptal edilinceye kadar geçen zaman içerisinde yapı ruhsatı alınarak başlanan ve tamamlanan, ruhsatının iptal edildiğine ilişkin bir bilgi ve belge de bulunmayan inşaatın, ruhsata aykırılı̆̆ tespit edilmeden ya da ruhsatı iptal edilmeden, sadece dayanağı imar ve parselasyon planı iptal edildiği gerekçesiyle durdurulmasında mevzuata uyarlık bulunmamaktadır." olarak ifade edilmiştir. Aynı konuda aynı Daire tarafından alınan 2002/4645 Esas, 
2004/685 Karar sayılı, 11.02.2004 tarihli kararda, “Imar planının yargı kararı ile iptal edilmesi bu plana uygun olarak alınmıs ruhsatları ortadan kaldırmayacă̆ından, yapının mühürlenerek durdurulmasına ilişkin işlemlerde hukuka uyarlık bulunmamaktadır.”; 2003/2547 Esas, 2004/6226 Karar sayılı 07.12.2004 tarihli kararda, “Davacıya ait inşaatın bulunduğu bölgenin imar planının ve parselasyon işleminin yargı kararı ile iptal edilmesi sonucunda, plansız alan haline geldiği ve yeni planın yapılmasından sonra taşınmazın durumunun değerlendirleceği açık olduğunda, inşaatın devamına izin verilmemesi yolundaki işlemde hukuka uyarlık bulunmamaktadır.”; 2010/9076 Esas, 2011/469 Karar sayıl1, 07.03.2011 tarihli kararda, "Uygulama imar planına karşı açılan davanın yargılama süreci içerisinde yapının inşaat ruhsatına uygun yapıldı̆̆ının belirlenmesi halinde, yapı ya da yapı kısımları kazanılmış hak kapsamında olur.”; 2003/3435 Esas, K. 2004/6378 Karar sayılı, 08.12.2004 tarihli kararda, “Bir bölgede yapılaşmaya olanak veren imar planı mahkemece iptal edildiği takdirde iptal tarihine kadar ilgilinin hilesi, hatasi ya da kusuru olmadan yapıya ruhsatına uygun olarak devam edilmesi durumunda mahkeme kararının verilmesini takiben davalı idarece inşaatın mühürlenmesi, yapının bu tarihe kadar tamamlanmış kısmının ise kazanılmış hakkın varlı̆̆ı nedeniyle korunması gerekmektedir.” denilmiştir.

İmar ve parselasyon planı mahkeme kararı ile iptal edildiği durumlarda, o plana uygun olarak alınmış olan inşaatta kazanılmış hakların göz önünde bulundurulması gerekmektedir. İptale konu bölgede, kat mülkiyeti veya kat irtifakı tescil edilmiş taşınmazlarda, yapılara verilen ruhsatın dayanağı olan imar planı ve parselasyon işlemleri mahkemece iptal edilmesinden dolayı dayanaksız kaldığından, bu işlemlerin de dayanağı kalmamaktadır. Ancak, kadastral parsele dönüşşşlemleri sırasında bu yapıların dikkate alınması gerekmektedir. Bu durumun, düzenleme öncesine dönülecek kadastral parsellerin beyanlar hanesinde gösterilmesi ve bağımsız bölümler üzerinde tesis edilen diğer kişisel ve ayni hakların bu bağımsız bölümlerin arsa paylarının hisseye dönüşmeleri nedeniyle hisseler üzerine taşınması gerekmektedir. Ayrıca, söz konusu yapıların kazanılmış haklar gözetilerek yeni yapılacak AAD işleminde de dikkate alınması ve mümkünse ruhsata bağlanması gerekmektedir.

\section{İptal Edilen AAD Kapsamında Oluşan Bir İmar Parseli ile Bu AAD Sahası Sınırları Dışında Kalan Bir Parselin Tevhidi İşlemlerinde Geri Dönüşüm}

İptal edilen AAD kapsamında oluşan bir imar parseli ile bu AAD sınırları dışındaki bir imar parselinin tevhidi işlemi, iptal edilen AAD üzerinden yapılan bir düzenleme olduğu için mevzuata uygun değildir. Tevhit ile oluşan yeni parsel kadastro ayırma çapı ile ifraz edilerek, AAD sınırları dışındaki parselin yeniden uygulama dışında bırakılması sağlanmalıdır. Bu doğrultuda, Danıştay 6'ncı Dairesi'nin 2002/2368 Esas, 2003/5127 Karar sayıl1, 24.10.2003 tarihli kararı, “iptal edilen düzenlemede yer alan parseller üzerinden yapılan düzenlemede mevzuata uyarlık bulunmadı̆̆ ’” yönündedir.

\section{İmar Parseli Satılmışsa Kamu Ortaklık Payına Giden Kısmın Geri Dönüşümü}

KOP'a giden hisse; ilgilisi feragat etmedikçe ya da ilgili idare tarafından kamulaştırılmadıkça, o kişi adına tescilli olmaya devam eder. İmar parseline giden hisse ile KOP’a giden hisse artık birbirinden bağımsız parsellerde yer aldığından imar parseli satıldığında, bu satış KOP’a giden kısmı kapsamaz (URL-9).

\section{Malikler Arası İpoteklerin Tapu Sicilinden Terkin Edildiği Durumda Geri Dönüşüm}

2981 sayılı Kanuna göre yapılan AAD işlemi ile kanuni ipotek tesisi mümkündür. Maliklerin rızaları veya mahkeme kararlarına istinaden tapu kütüğ̈̈nden kanuni ipotek terkini yapılan parseller, hisselerle ilgili güncel tapu kayıtları dikkate alınıp, bunlara DOP miktarları eklenerek son malikler adlarına tescil edilmelidir.

\section{Malikler Arası İpoteklerin Tapu Sicilinden Terkin Edilmediği Durumda Geri Dönüşüm}

Kazanılmış hak, Yargıtay tarafından “yasalara uygun olarak gerçekleşen hak” olarak tanımlandığına; Danıştay tarafından da kazanılmış hakkın var olup olmadığı, genel hukuksal durumların kişilere yönelik uygulanıp uygulanmadığının “kural 
tasarruflarla kabul edilen hukuksal olay ve esaslar kişisel durumlara dönüşmedikçe, kazanılmış hakların varlı̆̆ından söz edilemez." hükmü uyarınca araştırıldığına göre, haksız ve hukuka aykırı uygulamalar kazanılmış hak yaratmamaktadır. Buna göre; 2981 sayılı Kanuna göre yapılan AAD işleminde dağıtım sonucu alması gerekenden fazla yer alan kişilerin bu fazlalığa gerekçe olan şuyulandırma işlemi mahkemece iptal edildiğinden ve ipotek işlemleri de dayanaksız hale geldiğinden, uygulama öncesi kadastral hak durumuna dönülmesi gerekir.

\section{Geri Dönüş İş Akış Diyagramları}

Geri dönüşüm işleminin sorunsuzca yürütülebilmesi ve uygulayıcılara klavuzluk etmesi açısından 5'inci Bölümde anlatılanlar dikkate alınarak iş akış diagramları oluşturulmuştur. İlgilisinin idare mahkemesinde AAD’nin iptali için kendi parseli ile ilgili olarak açtığı dava ile başlayan süreç Şekil 2'de; idare mahkemesinin iptal kararının, yetki ve şekil eksikliği yönünden ya da sebep, konu ve maksat yönünden olması durumunda ilgili idarece yapılacak işlemler Şekil 3 ve Şekil 4'te; iptal kararının uygulanmasında idarece işlem yapılmaması durumunda ilgilisince yapılabilecekler Şekil 5'te; ilgilisinin açtığı davada tapu kayıtlarının düzeltilmesi Şekil 6'da gösterilmiştir.

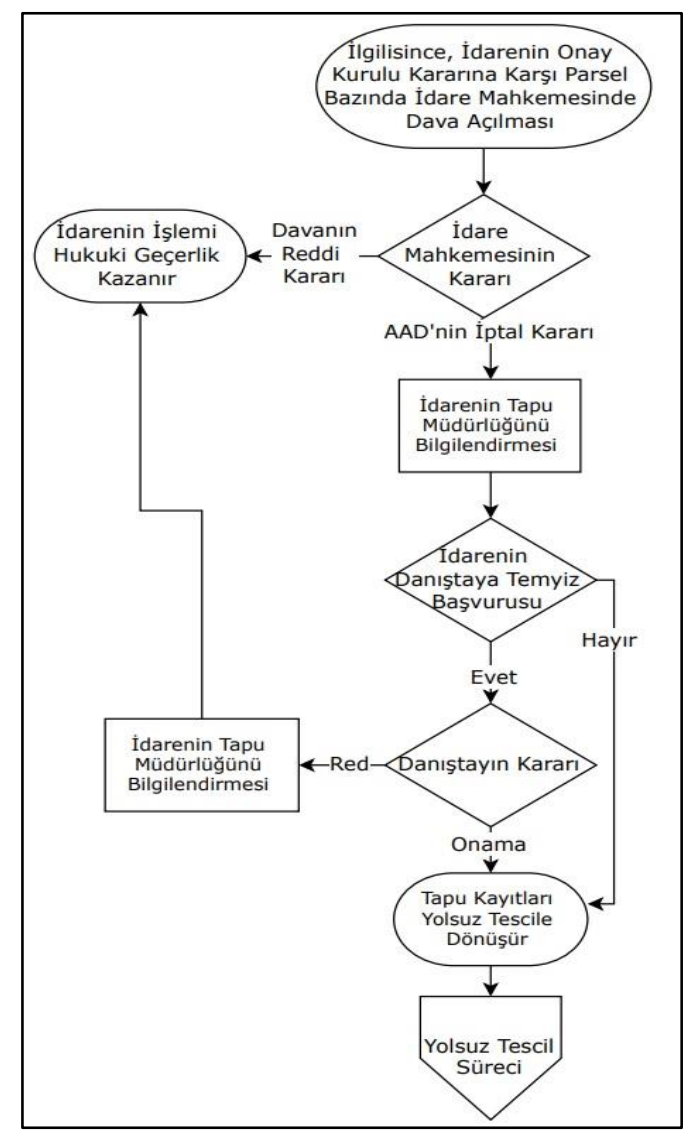

Şekil 2: Ilgilisinin idare mahkemesinde AAD’nin iptali için kendi parseli ile ilgili olarak açtığı dava ile başlayan süreç (Hacıosmanoğlu, 2019)

\section{Sonuçlar}

AAD işlemleri idarenin onay kurulu kararı ile yapılmaktadır. AAD’nin yürürlükteki kurallara uygun biçimde yapılıp yapılmadığının denetim aracı idari yargıdır. Taşınmaz malikleri, idarenin işlemine karşı menfaatlerinin ihlal edildiği gerekçesiyle idari yargıda hak aramaktadır. İmar planının hayata geçirilmesi aşamasında yapılan hukuki ve teknik hatalar ile eksiklikler, AAD’nin idari yargıda açılan davalar sonucunda iptal edilmesine sebep olmaktadır. AAD’nin idari yargıda iptal edilmesi sonrası yapılacak işlemler konusunda, 3194 sayılı İmar Kanunu’nun 18. Maddesi’nde ve Arazi ve Arsa Düzenlemesi 
Hakkında Yönetmelik’te yapılan son değişikliklerle geri dönüşüm işlemleri ile ilgili getirilen hükümler olumlu ancak, karar verici ve uygulayıcıları yönlendirici yeterlilikte olmadığı söylenebilir. İptal sonrası yapılacak geri dönüş işleminin doğru bir şekilde yapılabilmesi oldukça önemlidir. İşlemler sırasında mülkiyet hakkı ihlal edilmemeli ve herhangi bir hak kaybına sebebiyet verilmemesi bakımından, düzenleme öncesi duruma dönülmesi işlemleri sırasında, her bir uygulama teknik ve hukuki açıdan kendi içinde değerlendirilmeli, kazanılmış hak irdelemesi yapılmalı ve Türk hukuk sistemimizin öngördüğü taşınmaz ilgililerinin iyi niyetli ya da kötü niyetli edinimlerine göre değerlendirilmeli, yargı kararları ve hukukun genel ilkeleri çerçevesinde gerekli incelemeler yapılarak ilgili idarenin iyi niyetli olarak makul bir süre içerisinde geri dönüşüm işlemlerini tamamlaması suretiyle yapılmalıdır. Bunlarla birlikte, geri dönüşüm cetvelleri yeni bir imar uygulamasına altlık teşkil edecek şekilde ve iptale konu uygulamaya tabi tutulan kadastral alan ile iptal kararı gereği düzenleme öncesi kadastral duruma geri dönülen alanın eşit olmasına dikkat edilerek düzenlenmelidir. Bunlarla birlikte, işlemlerin kontrol ve tescil aşaması olan kadastro ve tapu müdürlüklerinin AAD işleminin iptali sonrası geri dönüşüm ile birlikte aynı zamanlı yeni bir AAD işlemini şart koşması da uygun değildir. 3194 sayılı İmar Kanunu'nun 18'inci maddesine bir fikra ilave edilerek; imar mevzuatına uygun inşa edilmiş yapı bulunan parsellerin kat malikleri adına tescil edilememesi durumunun ortadan kaldırılarak, hukuki ve fiili imkansızlıkların önüne geçilmesi uygundur. Böylece, geri dönüşüm çalışması sonrası yapılacak yeni AAD işleminde yeni bir mağduriyet ortaya çıkmamış olacaktır.

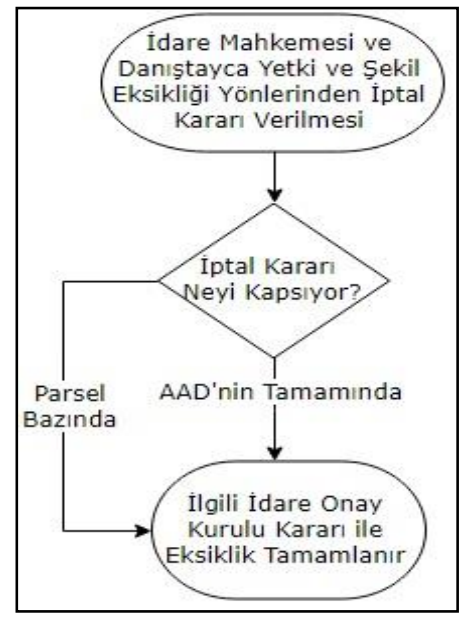

Şekil 3: Yetki ve şekil eksikliği yönünden iptal kararı verilen AAD’nde idarelerce yapılacak işlemler (Hacıosmanoğlu, 2019)

Bu makalede yukarıda belirtilen konular dikkate alınarak oluşturulan sonuç ve öneriler şunlardır:

- Aradan yıllar geçtikten sonra gelen AAD iptal kararının gereği yerine getirilirken, edinilen hakların iyi niyetli veya kötü niyetli oluşu yanı sıra, özellikleri ve sonuçları açısından da yargı kararları ve hukukun genel ilkeleri çerçevesinde ayrıntılı incelenmelidir.

- Kazanılmış hakların korunması ve mülkiyet hakkının ihlal edilmemesi açısından her geri dönüşüm çalışması, kendi uygulama alanındaki hukuki ve teknik durumuna göre değerlendirilmelidir.

- İdarelerin mahkeme kararlarını uygulaması hukuki bir zorunluluk olduğundan, ilgili idarenin iyi niyetli olarak bölgenin büyüklüğü, teknik ve hukuki zorluklarına göre mümkün mertebe en kısa sürede tekrar tapu tescillerini tamamlaması önemlidir.

- $\quad$ AAD, yetki ve şekil eksikliği yönünden hukuka aykırı bulunarak iptal edildiyse; idare aynı yolla bir karar alarak bu eksikliği giderebilmektedir. Ancak, AAD, sebep, konu ve maksat yönlerinden iptal edilmişse; bu durumda AAD 
işleminin tamamen yok sayılması ve makul bir süre içerisinde ortadan kaldırılması gerekmektedir.

- Yapılaşma oluşmuş olan bir bölgede AAD işleminin idari yargıda iptal edilmesi ile bölgenin mülkiyet ve plan durumu sürüncemeye dönüşebilmektedir. Bu sebeple, AAD işlemlerinin doğru uygulamaları, bölgenin ihtiyacına cevap verecek plan ve AAD yönteminin belirlenmesi önemlidir. AAD’nin iptal kararı sonrası oluşabilecek mülkiyet sorunlarının giderilmesi, maliklerin iptale konu imar parselini uzun yıllar kullanımları sonucu benimsemeleri nedeniyle ve geri dönüşüm çalışması sonrası yeni yapılacak uygulamayı kolaylaştırmak için trampa, takas veya eş değerlik usulü gibi farklı yöntemlerin mevzuata dahil edilmesi önemlidir.

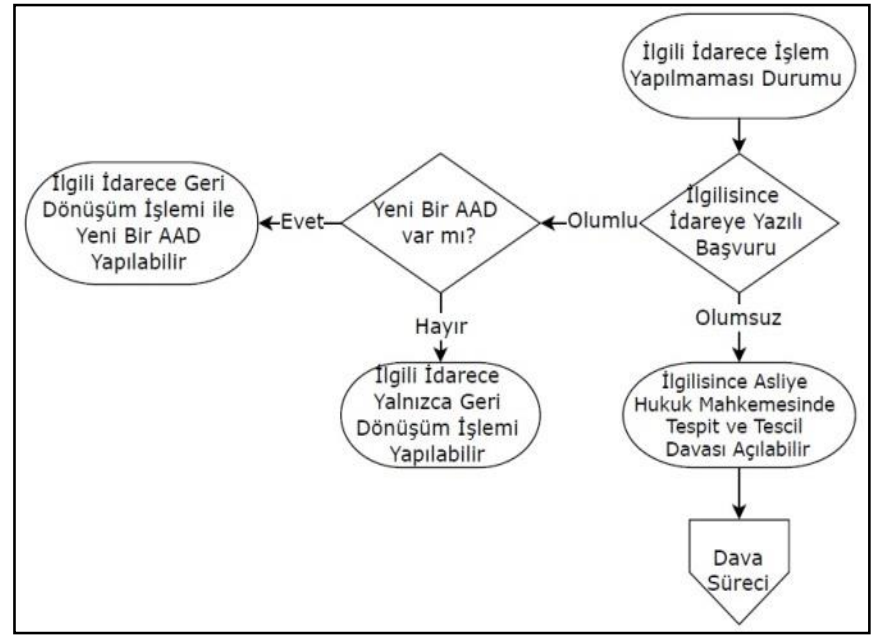

Şekil 4: Sebep, konu ve maksat yönünden iptal kararı verilen AAD’nde idarelerce yapılacak işlemler (Hacıosmanoğlu, 2019)

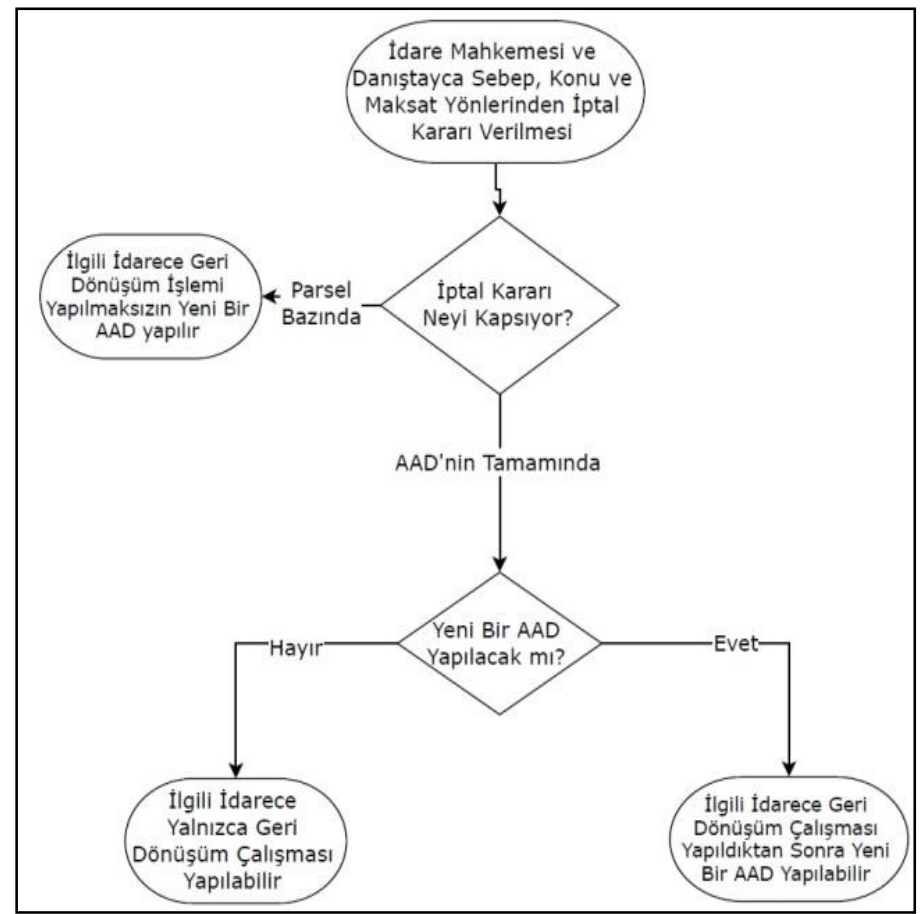

Şekil 5: Iptal kararının uygulanmasında idarece işlem yapılmaması durumunda ilgilisince yapılabilecekler (Hacıssmanoğlu, 2019)

- Geri dönüşüm ile birlikte yeni bir AAD’ye dair bir zorunluluk yoktur. İdarenin zorunluluğu; her halükarda hukuka aykırılığı saptanan ve yasal dayanaktan yoksun hale gelen AAD işlemini geri almaktır. Ancak, mümkünse idarelerin, mahkemenin iptal gerekçeleri doğrultusunda geri dönüşümden sonra tekrar yeni bir AAD işlemi yapmaları 
uygundur.

- Kadastral hak durumuna dönüldüğünde DOP miktarının son malik adına yazılması uygundur.

- Münferit olarak; tek bir parsel bakımından iptal kararı verildiğinde veya bir diğer ifade ile kısmi iptallerde; bu parselin diğerlerinden ayrı tutularak düzenleme öncesine döndürülmesi teknik olarak olanaksızdır. Çünkü; tüm parsellerden DOP kesilmektedir. Bir parselden yapılan kesinti geri alındığında bu tüm parselleri ve dağıtım işlemlerini de etkilemektedir. Bu durum, yargı kararlarında yeterince gözetilmemektedir. Konu yalnızca hukuksal olabilirlik açısından ele alınmaktadır. Bu sebeple, mahkemece karar verilen tapu iptallerinin gerçekleştirilmesi için yapılacak kadastro parsellerine geri dönüş hem teknik yönden hem de mükerrer haklara sebebiyet verdiğinden (parsellerin eski yerlerinin başka parsellere tahsis edilmiş olması) mümkün olmamaktadır. Çünkü, iptal edilen AAD ile kadastro parseline dönecek dava konusu parselin AAD işlemi ile sınırları değişmekte, hatta çoğu zaman eski mülkiyet durumu değişmektedir. Bu nedenle kısmı iptallere veya parsel bazlı iptallere, adli yargıda yine aynı sonuçları doğuracak tapu iptal davası açılmadan anayasanın 138'inci maddesi ve bu fikraya paralel olarak getirilen 2577 sayılı İdari Yargılama Usulü Kanunu’nun 28'inci maddesinin 1'inci fikrasına istinaden, birinci AAD işlemini yapan idarenin iptal kararına uygun olarak kadastral parsellere dönülmeksizin ikinci AAD işlemi yapılmalıdır (Ergen, 2006).

- Sadece talimat ve görüşlerle veya Türk Medeni Kanunu, İmar Kanunu, Kat Mülkiyeti Kanunu gibi mevzuattaki diğer kanunlarla mülkiyet hakkıyla ilgili tesis edilmiş bütün işlemleri geri almak ve yeniden tesis etmek her zaman kolay olmamaktadır. Maliklerin kazanılmış haklarının korunması açısından ve geri dönüşüm işlemlerinde idareler arasında uygulama birliğinin oluşabilmesi için yönetmeliğin detaylandırılması uygun olacaktır.

AAD’nin idari yargı tarafından iptali; düzenleme sınırının tümünde veya tek bir parsel bazında olabilmektedir. Ancak, geri dönüşüm işlemlerinde çoğu zaman başka parseller de etkilenmektedir. İdari yargı denetiminden geçerek AAD’nin tümünde iptal kararı verilmesi, davayı açan malikin yanı sıra düzenleme sahasındaki tüm malikleri etkileyebilmektedir.

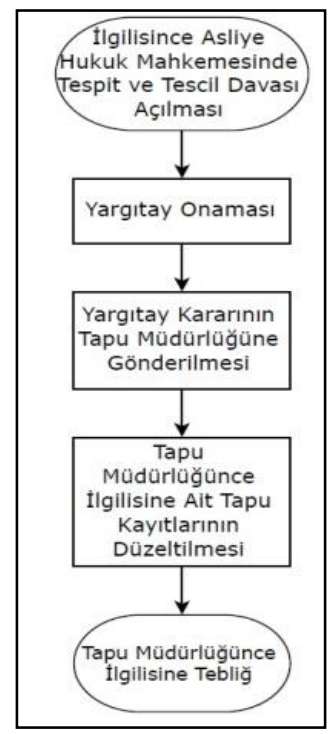

Şekil 6: Ilggilisinin açtığı davada tapu kayıtlarının düzeltilmesi

Malikleri tarafından uzun yıllar imar parseli olarak kullanılan taşınmazların geri dönüşüm çalışmaları maliklere ve idarelere birtakım zorluklar yaşatmaktadır. İptal tarihine kadar müstakil olarak kullanılan bir imar parseli iptalden sonra geri dönüşüm 
işlemi ile kadastral parsel olarak tescil edilmekte ve hisseli parsel haline dönmektedir. Yargının iptal kararına kadar geçen süre içinde tapu sicilinde taşınmazın hukuki durumu ve maliklerin hisse durumunu değiştiren işlemler gerçekleşebilmektedir. Bu durumda, geri dönüşüm işlemlerinde alansal olarak kök parsellere geri dönüşümün yanında maliklerin tapu kütüğünde taşınmaz üzerinde kayıtlı takyidat bilgileri de kök parsellere taşınmaktadır.

Geri dönüşüm işlemlerinde yaşanılan sorunları en aza indirgemek, doğru bir uygulama birliği oluşturabilmek ve geri dönüşüm işlemi sonrasında açılacak iptal ve tazminat davalarının önlenmesi açısından uygulayıcı ve denetleyici birimler ile mühendislere önemli görevler düşmektedir. Yargının iptal kararının gerekçelerine ve geri dönüşümden etkilenen alana göre yapılacak işlemleri içeren yasal düzenlemelerin ayrıntılandırılması önemlidir.

\section{Kaynaklar}

Akı, E. (1993). Hukukun Temel Kavramları (3. bask1). Fakülteler Kitabevi, İzmir.

Akış, E. (2014). İmar Hukukuna Giriş (2. baskı). Kent Eğitim Danışmanlık, İzmir.

Akyılmaz, B. (2000). İdari Usul İlkeleri Işı̆̆ı̆nda İdari İşlemin Yapılış Usulü, Yetkin Yayınları, Ankara.

Çelik, K., Uzun, B., Demir, O., \& Nişancı, R. (2000). İmar Uygulamalarında Yargı Denetimi Sonuçlarının İkinci Uygulama Yönünden Değerlendirilmesi. Samsun Barosu Dergisi, (2-3), 87-88.

Ergen, C. (2006). Arsa ve Arazi Düzenlemeleri (2. Baskı). Seçkin Yayıncılık San. ve Tic. A.Ş., Ankara.

Hacıosmanoğlu, S. (2019). Arazi ve Arsa Düzenlemelerinin Geri Dönüşüm İşlemlerinde Yargı Kararlarına Dayalı Çözüm Önerileri (Yüksek Lisans Tezi), Yıldız Teknik Üniversitesi Fen Bilimleri Enstitüsü, İstanbul, Türkiye.

Kalabalık, H. (2014). İmar Hukuku Dersleri (6. Bask1). Seçkin Yayıncılık San. ve Tic. A.Ş., Esentepe Kampüsü, Sakarya.

Koçak, H., \& Beyaz, M. (2015). 3194 sayılı Kanunun 18’ inci Maddesi Gereğince İmar Uygulamaları, Sonsöz Gazetecilik, Matbaacılık, Reklamcılık, İnş. San. ve Tic. Ltd. Şti., Ankara.

Köktürk, E. (2007). Arsa Düzenlemeleri ve Yargı İlişkisi (18. Maddenin İdari Yargıda Íptali ve Ortaya Çıkan Sorunlar) Semineri. HKMO İstanbul Şube Toplantı Salonu, İstanbul.

Köktürk, E. (2009). Arsa Düzenlemesinin İptali ve Ardından Yapılacak İşlemler. HKMO İstanbul Şube Bülteni, Şubat 2009, 3-6.

Sever, D.Ç. (2006). Danıştay Kararları Işı̆̆ında İdare Hukukunda Kazanılmış Hak (Yüksek Lisans Tezi). Ankara Üniversitesi Sosyal Bilimler Enstitüsü, Ankara, Türkiye.

Tütüncü, R. (2015). Danıştay Kararları Işı̆̆ında Imar Hukukunda Kazanılmış Haklar (Yüksek Lisans Tezi), (s. 12), Gazi Üniversitesi Sosyal Bilimler Enstitüsü, Ankara, Türkiye.

Ulusoy, A. (2004). Hukuk Devleti ve İdari Faaliyetlerin Gerekleri Yönünden Kazanılmış Hak Kavramı. Ankara Barosu tarafindan düzenlenen Hukuk Kurultayl, 172-173.

URL-1: T.C. Danıştay Başkanlığı, Danıştay Dergileri, http://www.danistay.gov.tr/dergiler.html (Erişim Tarihi: 29 Eylül 2018).

URL-2: T.C. Kazancı İçtihat Bilgi Bankası, http://www.kazanci.com (Erişim Tarihi: 2 Ekim 2018).

URL-3: Kararara.com, Yargı Kararı Arama Motoru, Emsal Karar Talep Forumları, Eşya Hukuku, 18 Madde Uygulamalarının Kadastro ve

Tapu Tescil ve Süreçler, 18. Madde Uygulamalarının Kadastro ve Tapu Müdürlüklerindeki Kabul ve Tescil Süreçlerinde Karşılaşılan Uygulama Sorunları, http://www.kararara.com (Erişim Tarihi: 2 Ekim 2018).

URL-4: Yargıtay Dergisi, http://www.yargitaydergisi.gov.tr (Erişim Tarihi: 22 Ekim 2018).

URL-5: T.C. Anayasa Mahkemesi Kararlar Dergisi, http://www.anayasa.gov.tr/icsayfalar/yayinlar/kararlardergisi.html (Erişim Tarihi: 23 Ekim 2018).

URL-6: T.C. Anayasa Mahkemesi, Kararlar Bilgi Bankası, https://kararlarbilgibankasi.anayasa.gov.tr (Erişim Tarihi: 27 Ekim 2018).

URL-7: Arslan, S., (2013). İmar Uygulamalarında Geri Dönüşüm, Tapu ve Kadastro Genel Müdürlüğü, Tapu Dairesi Başkanlığı, https://www.tkgm.gov.tr/sites/default/files/icerik/ekleri/imar_uygulamalarinda_geri_donus-imar_planlari_ve_imar_uygulamalarinin_ iptali_sonrasi_uygulamalar.pptx (Erişim Tarihi: 27 Ekim 2018).

URL-8: Koçak, H., (2015). "Parselasyonun İptali ve Geri Dönüşüm”, http://www.tapu-kadastro.net/ (Erişim Tarihi: 27 Ekim 2018).

URL-9: Koçak, H., (2013). “18 Uygulamasının İptali ve Geri Dönüşüm”, http://www.tapu-kadastro.net/ (Erişim Tarihi: 24 Kasım 2018). 
URL-10: Koçak, H., (2012). “3194 Sayılı İmar Yasası'nın 18'inci Madde Gereğince Yapılacak Parselasyon ile İlgili Genel Müdürlük Muktezaları”, http://www.imarkadastro.com/ (Erişim Tarihi: 24 Kasım 2018). 